\title{
A!
}

This is an electronic reprint of the original article.

This reprint may differ from the original in pagination and typographic detail.

Pitman, Sophie; Smith, Pamela ; Uchacz, Tianna; Taape, Tillmann; Debuiche, Colin

\section{The Matter of Ephemeral Art: Craft, spectacle, and power in early modern Europe}

Published in:

RENAISSANCE QUARTERLY

DOI:

10.1017/rqx.2019.496

Published: 01/01/2020

Document Version

Publisher's PDF, also known as Version of record

Please cite the original version:

Pitman, S., Smith, P., Uchacz, T., Taape, T., \& Debuiche, C. (2020). The Matter of Ephemeral Art: Craft, spectacle, and power in early modern Europe. RENAISSANCE QUARTERLY, 73(1), 78-131.

[0034433819004962]. https://doi.org/10.1017/rqx.2019.496

This material is protected by copyright and other intellectual property rights, and duplication or sale of all or part of any of the repository collections is not permitted, except that material may be duplicated by you for your research use or educational purposes in electronic or print form. You must obtain permission for any other use. Electronic or print copies may not be offered, whether for sale or otherwise to anyone who is not an authorised user. 


\title{
The Matter of Ephemeral Art: Craft, Spectacle, and Power in Early Modern Europe
}

\author{
PAMELA H. SMITH, Columbia University \\ TIANNA HELENA UCHACZ, Columbia University \\ SOPHIE PITMAN, Aalto University \\ TILLMANN TAAPE, Columbia University \\ COLIN DEBUICHE, University of Rennes
}

\begin{abstract}
Through a close reading and reconstruction of technical recipes for ephemeral artworks in a manuscript compiled in Toulouse ca. 1580 (BnF MS Fr. 640), we question whether ephemeral art should be treated as a distinct category of art. The illusion and artifice underpinning ephemeral spectacles shared the aims and, frequently, the materials and techniques of art more generally. Our analysis of the manuscript also calls attention to other aspects of art making that reframe consideration of the ephemeral, such as intermediary processes, durability, the theatrical and transformative potential of materials, and the imitation and preservation of lifelikeness.
\end{abstract}

\section{INTRODUCTION: WHAT IS EPHEMERAL ART?}

THE SUBJECT OF ephemeral art has moved in and out of focus as a research object for art historians, usually providing a means to explore the work of individual artists, from Brunelleschi to Rubens and beyond, who were involved in triumphal and joyous entries and court festivities, or to study the iconographic and allegorical programs that articulated, via spectacle and artworks, the political negotiation between rulers, cities, and subjects. The increased attention to court culture that took hold in the 1980s resulted in an expansive exploration of

The authors of this article sincerely thank Jo Kirby, Christine Göttler, and Diane Bodart for stimulating lectures and discussions, and Naomi Rosenkranz and the participants in the fall 2017 lab seminar for their research and laboratory work. Research for this article has been supported by NSF1430843, NEH RQ-249842-16, and the Henry Luce, Gladys Krieble Delmas, and Florence Gould Foundations. This article has been published during Sophie Pitman's time on the "Refashioning the Renaissance" project, which has received funding from the European Research Council (ERC) under the European Union's Horizon 2020 research and innovation program (grant agreement No. 726195). Unless otherwise specified, all translations are our own.

Renaissance Quarterly 73 (2020): 78-131 (C The Author(s) 2020. Published by the Renaissance Society of America.

doi: $10.1017 /$ rqx.2019.496 
the work of artists and artisans in creating spectacular court events, as well as ephemeral objects such as banners and pennants for processions, tribunes for horse races, backdrops and macchine (stage machinery) for theater performances, triumphal arches, enormous sculptures in papier-mâché, sugar sculptures for noble weddings, temporary architectural structures for staging events, and other such works.

Not all ephemeral art was actually ephemeral. Much was meant to be temporary, but some survived to be reused or treasured in collections up until the present. And while the materials and actions involved in processions, banquets, fireworks displays, and nuptials were short-lived, they did aim, by means of spectacle, to create or consolidate a culture of memory among onlookers and subjects, frequently appearing in more durable material objects such as printed texts and images, paintings, and narrative forms. Indeed, ephemeral displays could have greater impact on viewers and contribute more to a court's reputation for magnificence and largesse than its permanent buildings. ${ }^{1}$ It could be argued that this so-called ephemeral art aimed to be maximally and durably affective and effective within the political and civic sphere, and thus might be regarded as possessing much greater reception, impact, and perhaps value in art historical narratives than, say, the panel paintings seen and enjoyed only by a few elite individuals. In a recent contribution to the study of the triumphal entry of Archdukes Albert and Isabella into Antwerp in 1599, Tamar Cholcman argues that such ephemeral spectacle must be understood as a distinctive art form that united a "plastic existence" of objects and a "recorded existence" of texts. The full meanings of the event could only be transmitted by the two components working together. ${ }^{2}$ Not all such spectacles included a recorded account; nevertheless, Cholcman is right to point to the two different components that made these events meaningful. It is arguable whether this makes ephemeral art distinct, however, as much of what we call art possesses both plastic and textual components, in the sense that a text-whether integral to an image, such as in an emblem, or in providing conceptual or iconographic underpinnings - extends and helps constitute the meaning of the work. While recognizing this characteristic dual feature of ephemeral art, this article raises a third component for consideration: the processes used to create what Cholcman labels the plastic existence of these works. Many scholars have discussed ephemeral displays as important in early modern political discourse, economic considerations, and culture; this article considers instead their material and technical side.

Ephemeral displays provided lucrative and welcome business for artists and artisans, and testimony in the sixteenth and seventeenth centuries shows that

\footnotetext{
${ }^{1}$ Tuohy, 235.

${ }^{2}$ Cholcman, 2014, 61, 139.
} 
they were not regarded as a lesser form of artistic production. Brunelleschi (1377-1446) famously made the stage machinery for mystery plays; ${ }^{3}$ Lucas Cranach (ca. 1472-1553) made military, tournament, and wedding decorations for the dukes of Saxony; ${ }^{4}$ Tintoretto (1518-94) derived a sizable portion of his income from painting furniture and scenery for theater; ${ }^{5}$ and Peter Paul Rubens (1577-1640) designed the joyous entry into Antwerp of Cardinal-Infante Ferdinand (1609-41) of Spain in 1635, as well as its spectacular description printed in elephant folio in 1642 (fig. 1). ${ }^{6}$ Giorgio Vasari (1511-1574) says of Battista Franco of Venice (d. 1561) that he went to Florence where "very great preparations were being made for the reception of the ... Emperor," and "Battista, being set to work, made a base all covered with figures and trophies for the statue on the Canto de' Carnesecchi.... Having therefore become known among the craftsmen as a young man of good parts and ability, he was much employed afterwards."7 In his life of Jacopo Pontormo (1494-1557), Vasari describes in vivid terms the synesthetic aims and multimedia production of a festival spectacle created by Andrea del Sarto (1486-1530), Piero da Vinci (ca. 1529-1553/54, Leonardo's father), Baccio Bandinelli (1488-1560), and many other well-known artists. Vasari notes that "from the works that he executed for this festival Pontormo gained, besides the profit, so much praise, that probably few young men of his age ever gained as much in that city." 8 In early modern Europe, ephemeral decorations could make an artist's reputation.

Ephemeral art also provides an opportunity to interrogate the performative nature and co-creation of artworks. The evocation of wonder and consolidation of memory that these temporary spectacles intended to provoke constituted important characteristics of cultural production in the early modern period,

${ }^{3}$ Vasari, 1912-15, 2:229-32.

${ }^{4}$ Heydenreich, 268-70.

${ }^{5}$ Krischel.

${ }^{6}$ See Gevartius, with forty-three etched plates, most by Theodoor van Thulden after designs by Peter Paul Rubens. Under the direction of alderman Nicolaas Rockox, city clerk Gaspar Gevartius, and Peter Paul Rubens, Antwerp prepared impressive street decorations, estimated at 36,000 guilders. This was financed by a loan of 8,000 guilders from Rockox, and an increased duty on beer. See https:/www.google.com/culturalinstitute/beta/asset/pompa-introitus/ IAEuQDiuBsfKlg.

${ }^{7}$ Vasari, 1912-15, 8:91.

${ }^{8}$ Vasari, 1912-15, 7:155. The elaborate multimedia production is evident in a chariot of the procession, representing the "Triumph of the Age and World of Gold," which carried a huge "globe of the world, upon which there lay prostrate on his face, as if dead, a man clad in armour all eaten with rust, who had the back open and cleft, and from the fissure there issued a child all naked and gilded, who represented the new birth of the age of gold and the end of the age of iron": Vasari, 1912-15, 7:154-55. The boy died shortly thereafter from the gilding. 


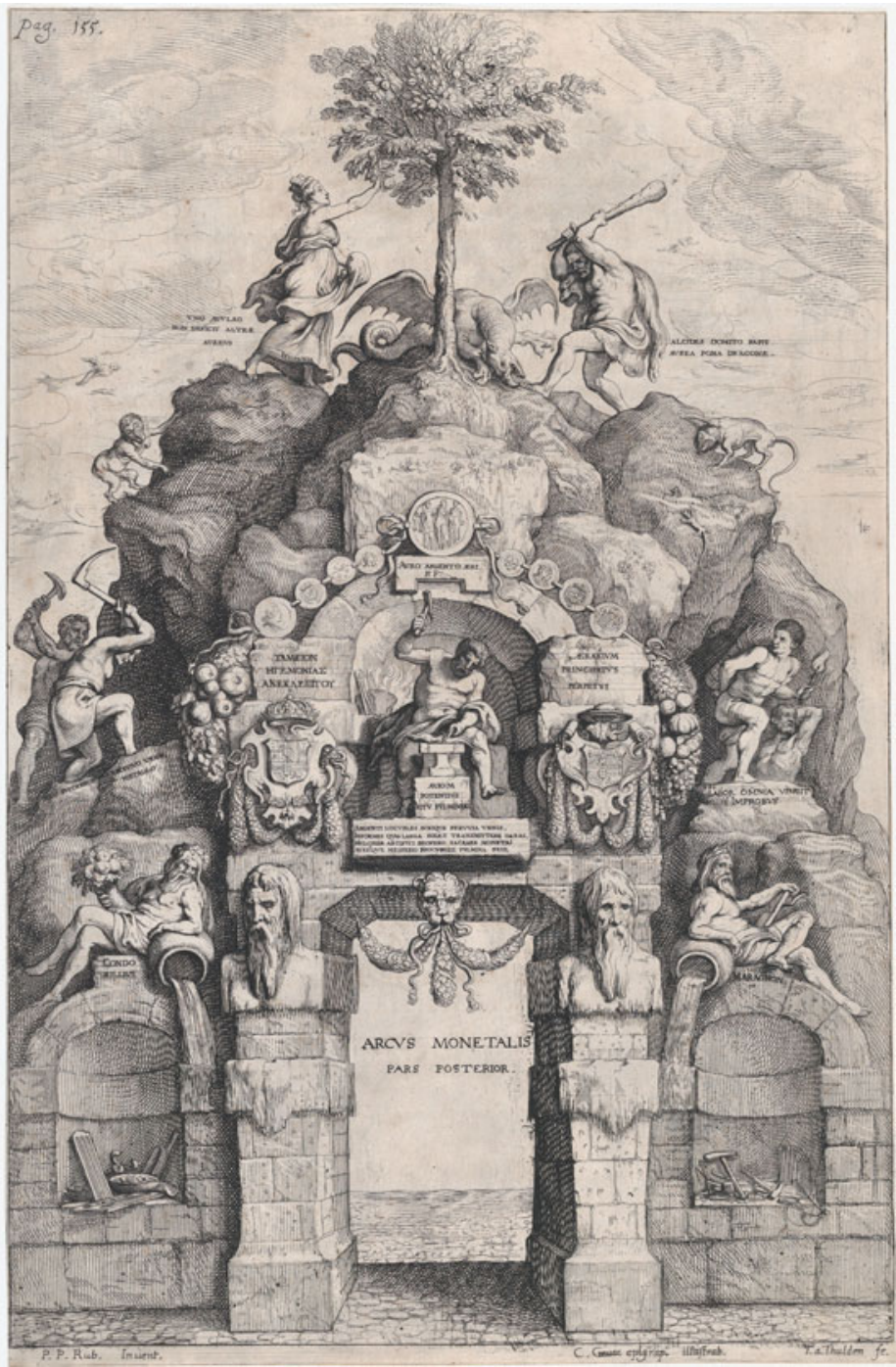

Figure 1. After Peter Paul Rubens. Arch of the Mint, 1635, etching, in Gaspar Gevartius, Pompa Introitus Ferdinandi Austriaci Hispaniarum Infantis (Antwerp: Johannes Meursius, 1641), page 155. Metropolitan Museum of Art, 51.501.7501. The Elisha Whittelsey Collection, The Elisha Whittelsey Fund, 1951.

and were explicitly articulated by both rulers and philosophers as links between art and governmentality. As Blaise Pascal noted in a scribbled analysis of the mechanisms of this theater of state, "the custom of seeing kings accompanied by guards, drums, officers, and all those things that bend the machine toward 
respect and terror, causes their face to imprint on their subjects respect and terror even when they appear by themselves, because one does not separate in thought their persons from the retinues with which they are ordinarily seen." Spectacle was capable of opening up "a channel in [the audience's] attention for the penetration of a doctrine or a feeling of amazement, suspension, or stupor that would facilitate the public's captivation." 10 The participatory nature of this art-within the civic sphere, between rulers and their subjects, and for cities asserting their autonomy-suggests that it is best understood not at the level of a reified outcome, but as a mode of art making, by which viewers co-create the meanings and effects of the work of art. ${ }^{11}$

Studying the making of ephemeral art also widens the field of investigation beyond the surviving artworks, of which there are relatively few-this is one important reason why, generally speaking, ephemeral art does not play a significant role in art historical narratives. Thus, the investigation of such temporary creations has necessitated a focus on process (including the process of spectacle and politics) rather than product. ${ }^{12}$ This has led to research into primary sources giving information on the materials and costs of these artworks, and the study of the descriptions and depictions of the events, leaving the historian frustratingly distant from the material objects themselves. This article argues that a slightly reoriented focus on process (here both the process of spectacle and the process of making artworks) can provide a new perspective on this category of art historical inquiry. It questions some of the unproductive hierarchies that inform art historical scholarship: for example, between individual artistic intention and viewer response, between artists as individual creative producers and as part of the collaborative teams fostered by noble and civic festivities, between so-called low (quotidian or decorative) and high art. It works, as well, to break down hierarchies among materials that are often used to define the relative values of works of art: stone vs. stucco, for example, or, cloth banners vs. panel paintings, and plastic materials such as cardboard, wax, and pourable stone and horn made from pulverized solids. ${ }^{13}$

${ }^{9}$ Pascal goes on to note skeptically that "the world, which does not know that the effect comes from this custom, thinks that it comes from a natural force; and from that come these words: 'The character of Divinity is imprinted on his face, etc.'”: Pascal, Pensées, as quoted in Marin, 14.

${ }^{10}$ Maravall, 252.

${ }^{11}$ See, for example, the accounts of the Lord Mayors' shows in Bergeron, 238-62.

${ }^{12}$ As Tierney recently does in considering the design, project management, and construction processes of Louis XIV's entrée into Paris in 1660.

${ }^{13}$ A recent exhibition at the Metropolitan Museum of Art, Relative Values: The Cost of Art in the Northern Renaissance (7 August 2017-28 February 2021), also seeks to dismantle these hierarchies by showing that paintings valued most highly in today's art market were less expensive and less sought after in early modern Europe than were so-called decorative objects. 
A late sixteenth-century manuscript source compiled in and around Toulouse provides an opportunity to examine these questions through the lens of process. ${ }^{14}$ This unusual source, BnF MS Fr. 640, contains 170 folios of many firsthand technical recipes for works of art, including some for the making of apparently ephemeral works. A close examination of this manuscript and its contents allows us to conclude that ephemeral art might be seen not as a separate category of art making but rather to share the characteristics of other fine arts in their aim to produce effective and affective responses by means of illusionism and imitation. Moreover, a focus on materials and processes breaks down the boundary between spectacular art and everyday low artworks such as painted cloth and papier-mâché boxes. Recent scholarship on artists such as Donatello (ca. 1386-1466) and Andrea del Verrocchio (1435-88) has shown that many artworks that art historians typically classify as painting or sculpture are in fact mixed media, using materials more usually associated with ephemeral art, such as cardboard, papier-mâché, stucco, cloth, paper, glue, and wax. ${ }^{15}$

Viewing art through this lens highlights skills, techniques, and materialscomponents of art that cannot be confined solely to a category of ephemeral production. Moreover, this focus on process demonstrates the commonalities between the making and ornamentation of durable quotidian objects and those intended for the highest levels of society, and brings into view techniques and materials that served an intermediary function in the creative process itself. Finally, the illusion and artifice that underpinned ephemeral spectacles-the materials made to look like something they were not—shared the aims, and, to a large extent, the materials and techniques of art making more generally. In the first half of this essay, "Spectacle, Making Meaning, and Memory," we sketch a Europe-wide survey of ephemeral art-including Toulouse where the manuscript Fr. 640 was composed - to bring into focus the ubiquity, range, and meanings of this art in the early modern period. Narrowing our gaze from political spectacle and meaning to their materialization in the making and materials of ephemeral artworks, we turn in the second half, "Making Ephemeral Art," to the insights that the recipes of BnF MS Fr. 640 provide into the making and understanding of art, ephemeral and otherwise.

\section{SPECTACLE, MAKING MEANING, AND MEMORY}

In the early modern period, so-called ephemeral artworks often provided the material staging for the short-lived performances of the theater of state

\footnotetext{
${ }^{14}$ Bibliothèque nationale de France (hereafter BnF), MS Fr. 640.

${ }^{15}$ Neilson; Zolli.
} 
(including those for church, city, and corporation), such as royal entries, weddings, funerals, tournaments, feasts, pageants, festivals, church and guild processions, literary competitions, and even impromptu public festivities. ${ }^{16}$ Early modern political theorists considered the representation of power to be part of the business of rule, and visual representations could be effective in transforming individuals' wills. As Pascal and others noted, ephemeral art in its affective sensory impact could evoke emotions seen as conducive to governance. It also formed part of a larger performative apparatus aiming to create or maintain positions of power, and contributed to a culture of memory in the minds of spectators that was also often recorded or illustrated in official narratives.

In its ability to transform the familiar, this impressive art also transformed social relations, as has been emphasized by theorists of spectacle, most famously by French philosopher Guy Debord, who has argued that "the spectacle is not a collection of images; rather, it is a social relationship between people that is mediated by images." 17 Early modern writers also understood—and theorized - the transformative power of art and its ability to convey abstract principles, observing that "the transitory cannot comprehend the eternal, and to come into its knowledge, one needs a visible means." ${ }^{18}$ This mediating function of art took place at various registers, including the iconographic, the political, the spatial, the material, and the sensory, and one role of ephemeral art was to facilitate the movement between them. Historians of art and culture have focused largely on the iconographic and political dimensions, due to the nature of the source materials: official publications that present elaborate allegorical public ceremonies, as well as eyewitness records that reveal how effectively that messaging worked. ${ }^{19}$ The present section of this essay surveys this historiographic approach, but shifts the focus slightly to emphasize the material and sensory dimensions of this art.

Early modern spectacle derived significant affective power from temporary material interventions in familiar public and semipublic spaces. For instance, describing an ingenious temporary arch with three facades erected for the

${ }^{16}$ Various models have been proposed to categorize such events, especially those orchestrated by the state. See, e.g., Geertz, whose notion of the "theater state" captures this expression of power especially in performance of ritual; and Giesey, who has distinguished between ceremonies of state-i.e., rituals imposed upon a sovereign—and spectacles of entertainment, organized irregularly and at will. Similarly, Lawrence M. Bryant notes that spectacles could be appended to ceremonies but were more a matter of entertainment than of political moment: Bryant, 7-8.

${ }^{17}$ Debord, 12.

${ }^{18}$ Pedro Caldéron de la Barca, quoted in Maravall, 252. Caldéron de la Barca (1600-81) was a playwright and poet of the Spanish Golden Age.

${ }^{19}$ For an excellent example of the latter, see Göttler. 
1565 entry into Florence, Giovan Battista Cini writes that it was "magnificent in composition, ... a thing of singular artifice for him who well considers it, which rendered that street, which is in itself as imposing and magnificent as any other that is to be found in Florence, even more imposing and more beautiful than could be believed." 20 When royal and imperial figures entered into free cities, large-scale ephemeral architecture made of wood, canvas, stucco, and paint transformed the urban landscape into a spatialized negotiation of privilege and obligation; lightweight painted sculpture of wood, pasteboard, and molded leather carried through the streets by hand or on triumphal chariots reinforced moral and social hierarchies through rituals of mass participation such as religious processions; lavish displays of costly fabric hung from windows or made into canopies, banners, and participants' costumes elevated to splendor a city's mundane walls and humble inhabitants, and forged community ties through civic celebration. Even snow, spontaneously sculpted by industrious and playful hands, could bring purveyors of so-called high and low culture into new relationships. ${ }^{21}$ Such visible and noteworthy material interventions in quotidian spaces signaled that something extraordinary was taking place; the spectator's awe ensured that the memory of the event would persist. For Samuel Pepys (1633-1703), the spectacle of the coronation of King Charles II on 23 April 1661 was so magnificently and violently overwhelming that he expected to never see anything as wonderful again in his life. He wrote in his diary that a woman in Kingstreet "had her eye put out by a boy's flinging a firebrand into the coach. Now after all this, I can say that, besides the pleasure of the sight of these glorious things, I may now shut my eyes against any other objects, nor for the future trouble myself to see things of state and show as being sure never to see the like again in this world." 22

This spectacle, however, impressed not only in its outcome but also as an undertaking. The collaborative imperative and rapid assembly of ephemeral decoration were part of the apparatus of awe. The official programs published to commemorate royal entries often emphasized the considerable cooperative labor that went into these events. The published account of the 1549 joyous entry of Philip II into Antwerp concludes with a summary of the extraordinary number of painters, sculptors, carpenters, and performers involved in the preparations for the five-day event. ${ }^{23}$ The arch of the Genoese Nation was reportedly constructed in seventeen days by 280 artists at a cost of 9,000 florins and

${ }^{20}$ Vasari, $1912-15,10: 56-57$.

${ }^{21}$ Scholten; Pleij.

${ }^{22}$ Pepys, 88.

${ }^{23}$ All three editions (Latin, French, and Dutch) note this on the penultimate page. See, for instance, Grapheus, 1550a, fol. Oiiir ${ }^{\mathrm{r}}$. 
fitted with over two dozen large-scale paintings on canvas by Frans Floris (1519-70), executed in approximately five weeks (fig. 2). ${ }^{24}$ The published description of the Duke of Anjou's entry into the same city on 19 February 1582 notes that the event was prepared in a mere six days and thus necessitated using materials close at hand. ${ }^{25}$ Naturally, as with all ambitious undertakings, the spectacle was a hard-won accomplishment. Streets had to be paved-or re-paved after being broken up by festival machinery—and building activity could be so intense that materials became scarce. ${ }^{26}$ Then, too, processions had to be carefully managed so that they "cannot be other than fine and honourable," as instructed by Duke Ercole d'Este himself in 1493: "It would seem well that the mouths of all those streets where they do not have to go should be closed, so the company does not disperse throughout the town, and that everyone goes along one route, and not too far ahead, as sometimes happens." 27

The early modern spectacle was a panoply of sensory experience that materialized the rhetoric of copia, or richness and abundance. Eyewitness accounts describe the visual and aural impressions left on spectators. In many cases, lavish banquets were held alongside public celebrations, extending the splendor into the realm of taste as well. For instance, the 1549 joyous entry of Philip II into Antwerp concluded the five-day celebration with an exclusive banquet followed by an impressive public fireworks display in the market square. In the official publication of the festivities, city secretary Cornelius Grapheus (1482-1558) describes the sumptuous banquet for the emperor, nobles, and honored guests featuring all manner of plates, platters, bowls, saucers, candles, some gilded and decorated with fruits and little animals, "all artfully constructed after life from sugar." ${ }^{28}$ There next followed dancing, and the night culminated in pyrotechnics. In the square stood expertly carved, life-size wooden statues of Adam, Eve, the serpent, and the Tree of Knowledge, which chronicler Juan Calvete de Estrella notes were "colored with such perfection that they seemed alive, and the apples so natural that whoever saw them would be tempted to try them." 29 The sculptures were fitted with tiny holes containing cartridges of gunpowder, which Grapheus reports were so artfully concealed within that

${ }^{24}$ Grapheus, 1550a, fol. Giiv .

${ }^{25}$ Despite this official narrative, it seems that preparations began in December of the preceding year. See Van Bruaene, 270-71. This point is also made by Visentin and Russell, 20.

${ }^{26}$ After the 1609 Lord Mayor's show in London, the parish of Christchurch petitioned for "recompence towards the pavement broken," as cited in Bergeron, 240.

${ }^{27}$ Quoted in Tuohy, 265-66.

28 "Konstelijck van enckelen suykere na dlevende gemaect": Grapheus, 1550a, fol. Oiir

29 "Dado su color tan perfeto, que parecian biuos, y las mançanas tan naturales, que quien las viera, le tomara codicia delas provar": de Estrella, fol. $259^{\mathrm{v}}$. 


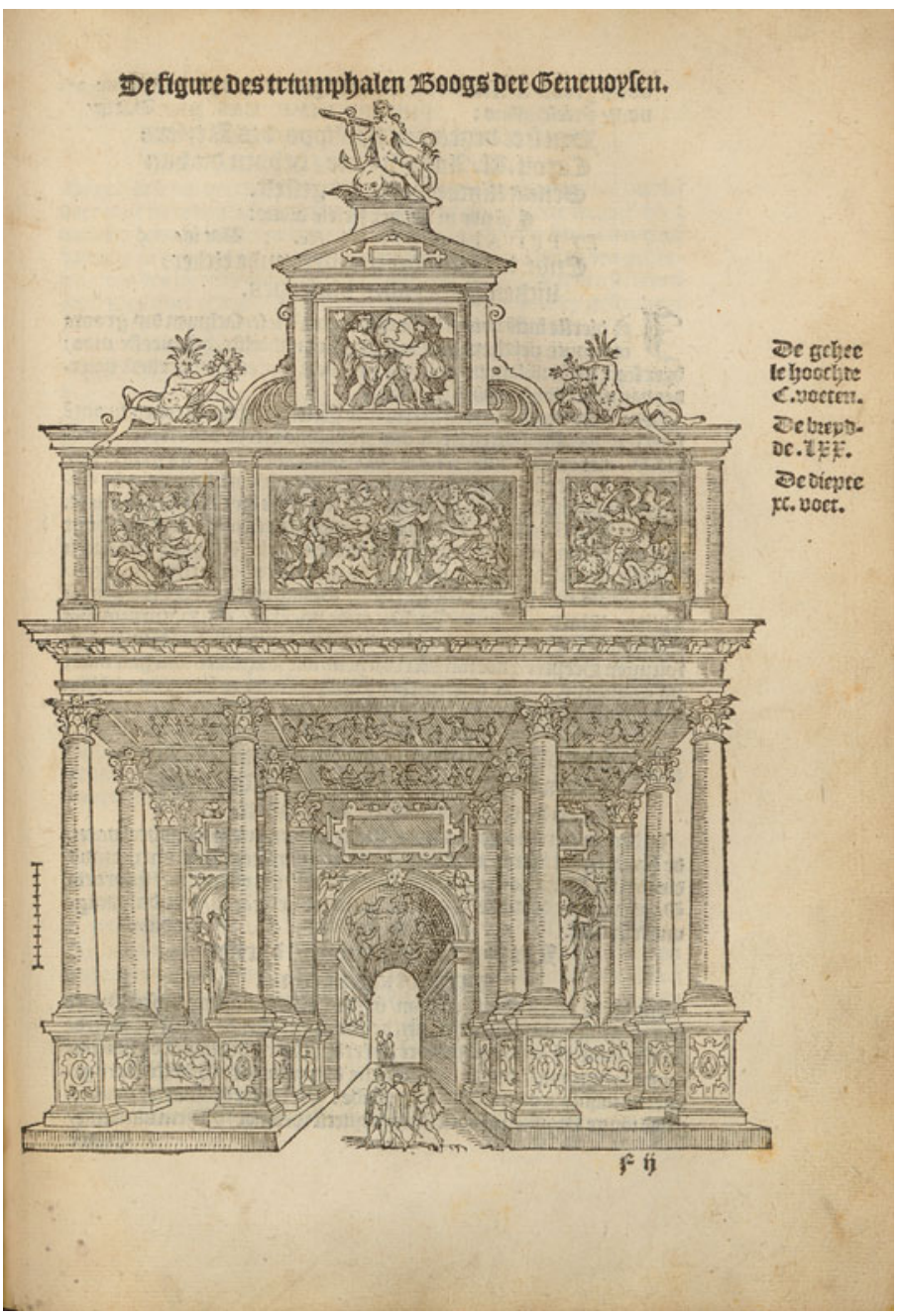

Figure 2. After Frans Floris. Arch of the Genoese Nation, in Cornelius Grapheus, De seer wonderlijcke, schoone, triumphelijcke incompst (Antwerp: Pieter Coecke van Aelst, 1550), fol. Fii ${ }^{\mathrm{r}}$. Collectie Stad Antwerpen, Erfgoedbibliotheek Hendrik Conscience, K 7613.

they could not be seen (figs. 3 and 4). ${ }^{30}$ At the appointed moment, a small flame started at Eve's foot and worked its way up to her abdomen; the explosion of her stomach shot tiny flames in all directions, leading to a series of secondary combustions, causing Adam, the tree, and the serpent to explode in quick

${ }^{30}$ Grapheus, 1550a, fol. Oiir ${ }^{\mathrm{r}}$ 




Figure 3. Kazimierz Siemienowicz. Pyrotechnic set piece of Bacchus (exterior), in Artis Magnae Artilleriae (Amsterdam: Jan Jansson, 1650), plate S. Courtesy of Science History Institute.

succession. ${ }^{31}$ Grapheus describes the explosions, not only in visual but also in auditory terms ("the crack and roar of a thousand shots"). ${ }^{32}$ Onlookers,

${ }^{31}$ See Bussels, 145.

32 "Tgekrack ende tgethier van duysent schueten": Grapheus, 1550a, fol. Oiiv . 


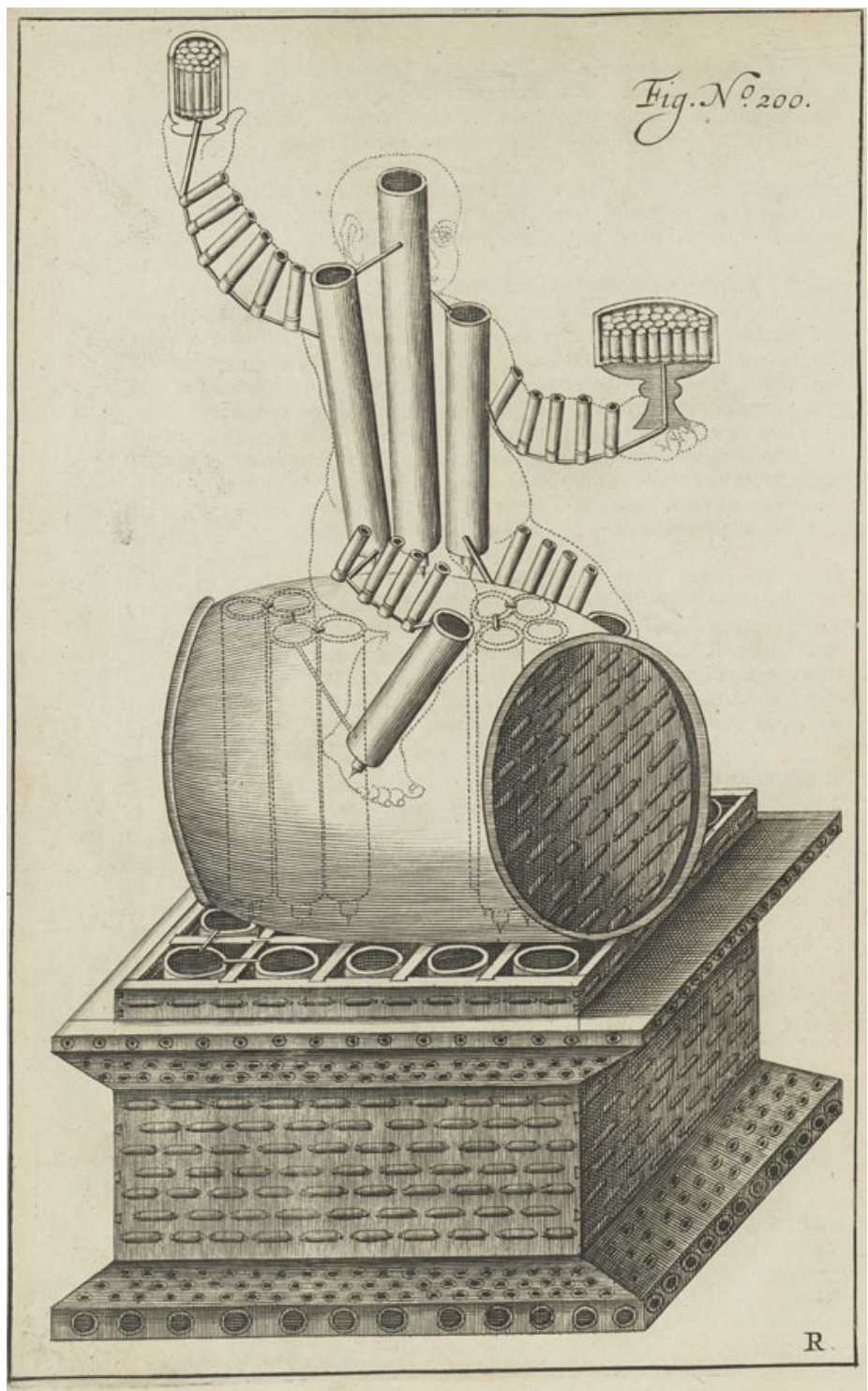

Figure 4. Kazimierz Siemienowicz. Pyrotechnic set piece of Bacchus (interior, showing profusion of cartridges concealed within), in Artis Magnae Artilleriae (Amsterdam: Jan Jansson, 1650), plate R. Courtesy of Science History Institute.

Grapheus notes, fled in fear, with some injured in the scramble. ${ }^{33}$ The ability for a work to cultivate suspense or awe was of particular importance, since as

${ }^{33}$ The injury to the crowd is elaborated in the Latin publication: Grapheus, $1550 \mathrm{~b}$, fol. Pii ${ }^{\mathrm{r}}$. 
Spanish humanist López Pinciano noted, "the new thing delights, and the amazing more so, and the marvelous and wondrous even more." ${ }^{4}$ Pursuing ever greater grandeur and novelty, ephemeral spectacles were an opportunity for artists to experiment, both in imitating the representation of power in antiquity, as well as in creating large-scale sculpture and novel architecture, for the technical prowess required by some of the designs was often easier to achieve in stucco and cardboard than in stone, metal, or wood.

Such spectacle was often underwritten by budget-busting expenditures. Lodovico Guicciardini (1521-89) notes that the Antwerp entry cost 130,000 scudi, while the splendid new Antwerp town hall cost 100,000 scudi. ${ }^{35}$ This extravagant sum was seen as so unconscionable by one local observer that the downpour that plagued the festivity was interpreted as evidence of God's wrath "because of the absurd expenditure that was there made." 36 At the court of the d'Este in Ferrara, food-including elaborate sugar sculptures-was the most costly component of the extraordinary expenditures for ducal weddings. In nuptial festivities there in 1491, for instance, the food cost the equivalent of building two large convents. ${ }^{37}$ But public festivities could also inspire awe on more modest budgets. Elements from previous events, such as the wood used to build scaffolding for spectator seating, could be reused so long as they had not been stolen, as they appear to have been with some regularity. ${ }^{38}$ After the 1635 Antwerp entry, an auction of the paintings on canvas proved unsuccessful, but the unpainted wood planks sold out. ${ }^{39}$ There is evidence that elaborate elements were also reused - a move that was both economically savvy and that helped to build traditions and meet viewer expectations, as was the case with the papier-mâché elephant, ship, sea monster, and giant of Antwerp, known as Druon Antigoon. ${ }^{40}$ Reuse could also be less literal. For instance, around 1545 Adriaen Isenbrandt was commissioned to make a new banner for the goldsmiths' guild in Bruges, which stipulated that their new

${ }^{34}$ Maravall, 215.

${ }^{35}$ Guicciardini, 86, 75. See also Göttler, 147.

${ }^{36}$ Quoted from Becker, 171.

${ }^{37}$ Tuohy, 236.

${ }^{38}$ Tuohy, 253. Thomas Middleton, a dramatist for the 1617 Lord Mayor's pageant, records that "no sooner is the speech ended but the Triumph is dissolved, and not possible to 'scape the hands of the defacer." Quoted in Bergeron, 243.

${ }^{39}$ Several of the paintings, as well as Rubens's oil sketches, are still extant: Christine Göttler, "Mount Potosí in Antwerp, 1635: Colonial Imagination and the Power of the Ephemeral," unpublished lecture, Columbia University, 24 April 2018.

${ }^{40}$ For the reuse of imagery, and presumably of the material floats, in Antwerp processions across the early modern period, see Cartwright; Göttler. The illustrated accounts of entries allow recurrent imagery to be tracked over time. 
banner faithfully reproduce the figures of the old one, allowing only the ornament to be updated into the fashionable antique style. ${ }^{41}$ This refreshing of an old model allowed its authority to persist despite new materials.

If public spectacle was intended to send a message, the specifics of political messaging could vary widely. Many joyous entries emphasized the power, munificence, and benevolence of both sovereign and city not only through iconographic means but also through material splendor-the use of expensive fireworks, pasteboard figures painted to imitate precious materials, or embellishments of (imitation) marble, gold, and precious stones. In other contexts, these same materials could convey messaging far removed from such golden-age concerns. Artisan Willem Weydts's eyewitness account of the Duke of Anjou's 1582 entry into Bruges describes a horrifyingly effective firework spectacle intended to undermine any perceived consensus about Anjou's appointment. A mock ship was constructed on the market square and filled with puppets, live cats, and gunpowder. Once lit, the explosion sent the puppets flying, and the cats, chained to the ship, made a horrible noise. For Weydts, the popular satirical association of cats with Catholics made clear an intended message: "this meant that the gueux [the party opposing Spanish rule] wanted to burn and destroy all Catholics." 42

Weydts's response illustrates that the messages and meanings of spectacles were co-created by spectators' participation and reaction, and like other cultural productions in the Renaissance were meant to be read at multiple levels. Nonetheless, even seemingly straightforward visual allegories were not always read as intended. The 1541 entry of Charles V into Milan, designed under the direction of Giulio Romano (1499-1546), featured an arch topped with a colossal statue group showing the Christian emperor on a rearing horse, trampling "an African Barbarian, another a Turk, and another an Indian" and conveying Charles's intention of bringing under his empire three parts of the world. ${ }^{43}$ Even the seemingly obvious trope of a conquering man might not dependably reflect the imperial person celebrated by this public event. A Milanese notary, Giovan Pietro Fossano, records his personal account of the festival in his diary and describes this arch as a theater with verses written around the display, surmounted by a large unbridled horse carrying a batonwielding man, who crush three men beneath them. ${ }^{44}$ When materialized in small objects, however, these abstract themes became sensory and tangible and functioned as takeaway messages. The largesse of a ruler or political

\footnotetext{
${ }^{41}$ Wilson, 526.

${ }^{42}$ Quoted in Van Bruaene, 277.

${ }^{43}$ Albicante, fol. Fiv ${ }^{r}$. With thanks to Diane Bodart.

${ }^{44}$ Quoted in Leydi, 235. With thanks to Diane Bodart.
} 
body was indicated by intended and unintended material distributions. The royal body, for instance, could be distributed to the people in the form of coins, food, and drink, while extensions of that body, such as the canopy of honor, might be torn to shreds in the course of a procession, with bits of the canopy salvaged as souvenirs by spectators, as attested in fifteenth-century Ferrara and Genoa. ${ }^{45}$ At the 1491 wedding of Anna Sforza and Ercole d'Este, the crowd not only took the baldacchino that had been carried above Anna, but forcibly made off with her horse as well. ${ }^{46}$ In 1473 the sugar sculptures, which had taken over eighty speziali (apothecary-grocers) a week's work, were plundered "by the multitude of the people ... everyone crying with one voice, 'Duca, Duca."' 47 But it was not always the spectators who did the plundering. Temporary artworks for royal entries in France were frequently confiscated and monetized by the king and his entourage. On the occasion of Louis XIII's entry into Toulouse in 1621, his officials made off not only with several arches, paintings, and tapestries, but also with the keys to the city gates, which had been handed over to the king as a token of obedience. The magistrates spent close to 1,500 livres to buy back various works of art and the city keys from the king's retinue. ${ }^{48}$

At whatever level the nuances of political messaging were understood, the sensory effect of public spectacle aimed to impress itself upon the memory of the spectator and gave rise to a distinctive commemorative culture. In response to humanist concerns about the weakness of human memory, some triumphal entries in sixteenth-century France specifically aimed at fostering a collective memory. ${ }^{49}$ Produced through the materials and objects of these spectacular events, collective memory could be further preserved and circulated in text or image. Official accounts and images often presented a picture of the occasion that reduced its semantic multiplicity even as they spread news of its magnificence. ${ }^{50}$ For example, depictions of celebratory fireworks displays from the seventeenth and eighteenth centuries often delivered an impression of the visual effects and overall design that could not have been seen cohesively during the

${ }^{45}$ Tuohy, 269-70.

${ }^{46}$ Tuohy, 270.

${ }^{47}$ Quoted in Tuohy, 272; on the speziali, see Tuohy, 275.

${ }^{48}$ Debuiche, 2012.

${ }^{49}$ Russell.

${ }^{50}$ Visentin and Russell, 18-19. For example, the royal entry of Louis XIV into Grenoble in 1701 was memorialized in an illustrated publication that gave a highly idealized account of the event. The publication was considered much more important than the event itself. See Sabatier, 168. Tamar Cholcman argues that, if emblems formed a part of the art, as they frequently did, the published account was the only way that spectators could receive the full import of the emblems' symbolic meaning. Cholcman, 2018. 
event, and were sometimes set down on paper before it had even taken place. ${ }^{51}$ Printed commemorations might appear in the form of single-sheet booklets, which could rapidly spread news of magnificent festivities, or as impressive volumes of several hundred pages, which consolidated collective memory through expansive description and copious illustration. ${ }^{52}$ Their aim was to indefinitely re-create the event, and to detail, explain, reorganize, and even correct its iconographic program. Of the entry of Louis XIV into Grenoble in 1701, Gerard Sabatier has written that "the real entrance was not the one that was realized, but the one that was published and engraved." 53 The ephemeral celebration thus became an enduring sign of good government, an address to posterity creating a history of virtuous rule.

The memory of spectacle also lived on in the objects crafted for the occasion. A striking example of such an object is Antwerp's papier-mâché colossus, Druon Antigoon, which first appeared at the joyous entry of Charles V and Prince Philip of Spain in 1549. Representing the legendary origins of the city, it embodied the collective identity of Antwerp's citizens as well as the knowledge of its historians and artists, who contributed to the giant's production. Druon Antigoon's fate is remarkable: unlike the great majority of the bespoke structures erected for the event, the papier-mâché giant was preserved and reused in subsequent urban processions until it was retired from circulation in the late nineteenth century. The figure of the Antwerp colossus, however, remains central to the city's processions to the present day, perpetuating and re-materializing a civic identity that has outlived any single physical object. ${ }^{54}$ A work of ephemeral art can thus endure long past its material presence through its creation of a political imaginary.

\section{Material Politics in Action: The Royal Entry of Charles IX into Toulouse} The staging of the royal entry of Charles IX into Toulouse in 1565 constitutes a revealing case study of the enactment of civic identity, royal splendor, and collective memory, and brings us one step closer to the anonymous technical manuscript composed in Toulouse, BnF MS Fr. 640, with its recipes for the transformation of materials into special effects. Toulouse was a powerful provincial capital with considerable political autonomy, governed by its own local magistracy, known throughout the Middle Ages as the capitulum (chapter).

${ }^{51}$ Werrett.

${ }^{52}$ Russell, 56; Visentin and Russell, 23.

${ }^{53}$ Sabatier, 166-70, asks "une entrée pour qui?" (“an entry for whom?”), making the point that the entry had many different audiences, including posterity and those who had not witnessed it in person.

${ }^{54}$ Göttler. 
In 1525 , the word capitulum in the municipal seal was changed to capitolium (capitol) —a subtle but significant lexical shift that lent to the city's governing body the clout of ancient Rome's center of power. ${ }^{55}$ Grown wealthy by its thriving crafts and commerce, especially the lucrative trade in the sought-after blue dyestuff known as pastel or woad, Toulouse fostered a lively intellectual and artistic environment. Renowned artists and architects were attracted to the city by the wealth and social ambition of the woad merchants' attempts to outdo each other in the size and splendor of their hôtels and other architectural commissions. They came, too, to work on Toulouse's fervently Catholic convents and churches, which between them claimed to possess no fewer than six of the bodies of the apostles, as well as the major construction sites of the cathedrals of Albi, Rodez, and Auch in the region. Toulouse also prided itself on its university, founded in 1229 and proudly represented as on a par with any European institution. ${ }^{56}$ The medieval Toulousaine tradition of the Jeux Floraux, an important annual poetry competition, speaks to this rich literary culture. The city's humanist renaissance provided a basis for a civic identity and authority based on local myth and ancient history. ${ }^{57}$

The making of art played a central part in crafting this identity, partly because Toulouse did not have much in the way of tangible, material remains upon which to rest its claims to an ancient and noble past. In contrast to Nîmes, Arles, and Narbonne, its rival cities in the ancient Roman province of La Narbonnaise, most of Toulouse's ancient brick structures had not survived or, as in the case of the capitole and the Roman amphitheater, had not yet been discovered or recognized as such. Forced to build a civic identity largely around immaterial ideals of a capitolium rather than its material foundations, the city's chief magistrates, known as capitouls, proved the city's long traditions by materializing its collective memory somewhat differently. Every year, the capitoulat appointed a chronicler to record significant events under their governance in the city's Annales, as well as a painter to record their individual portraits in depictions of these affairs. The right to have one's likeness captured was in itself a mark of distinction, since the ius imaginum (the legal right to display a portrait as a mark of office) was usually reserved for the nobility and only exceptionally extended to high-ranking patricians. ${ }^{58}$ Toulouse's identity was to no small degree based on the remarkable longevity of the collective urban memory of these Annales, going back as far as 1295 (fig. 5).59 The royal entry of

\footnotetext{
${ }^{55}$ Debuiche, 2016, 1:51. See also Schneider, 70.

${ }^{56}$ Labrousse, 505-20; Lemerle, 99; Ferté.

${ }^{57}$ On the city's local renaissance, see Schneider, 45-89. See also Toulouse Renaissance.

${ }^{58}$ Catel, 137; Mesuret, 279-80; on the ius imaginum, see Giroire, 118.

${ }^{59}$ On the Annales, see Bordes.
} 


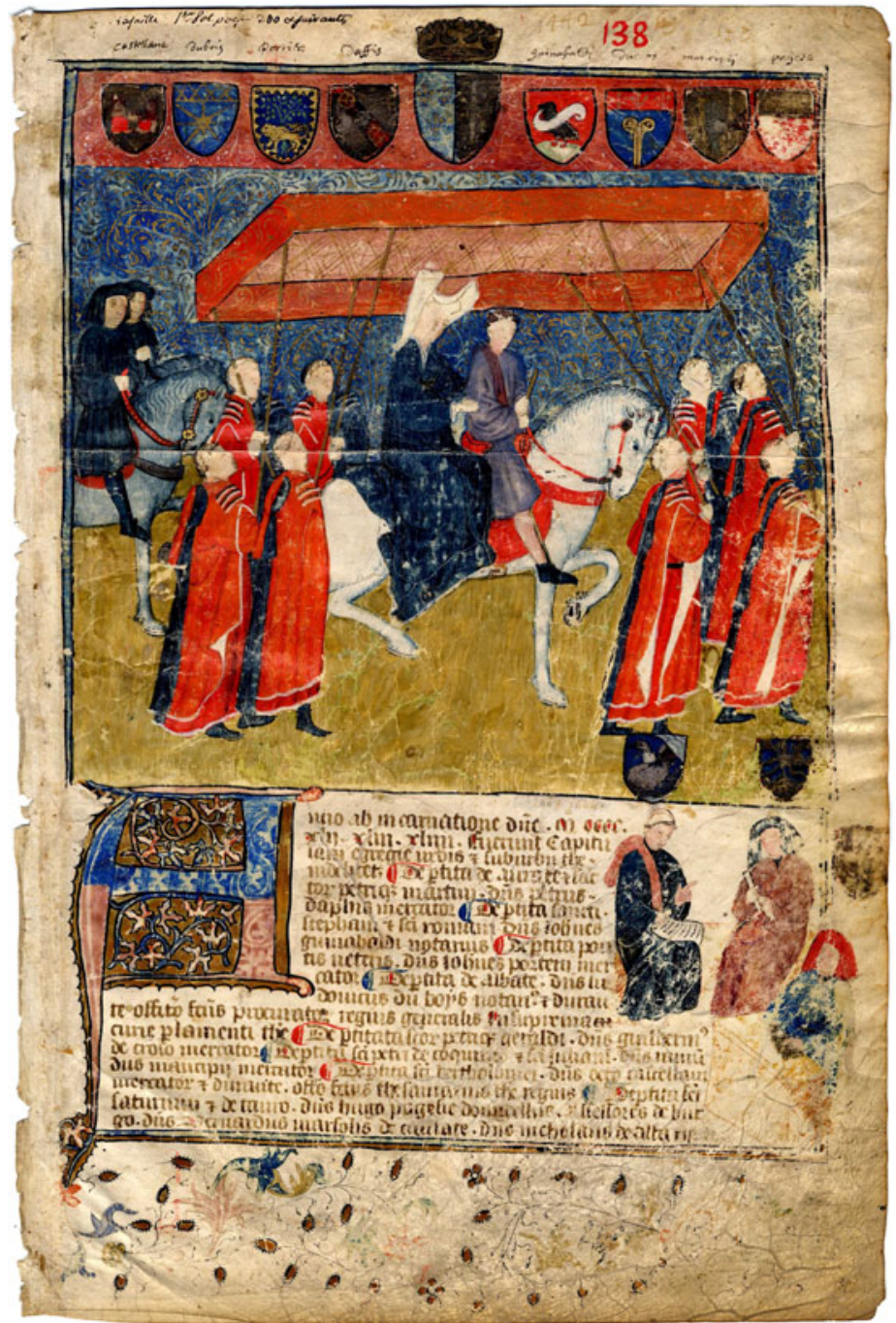

Figure 5. The Toulouse Annales and its capitouls. An illumination in the city's book of histories showing the entry of Queen Marie d'Anjou and the Dauphin. Archives municipales de Toulouse, BB273, 1442-45, chronique 137. (C) Ville de Toulouse, Archives municipales.

Charles IX in 1565 was commemorated in the text of the Annales and an accompanying painting. The image itself has not survived, but city account books attest to its commission: "pay Serve Cornoailh, master painter of Toulouse, the sum of 70 livres tournois, allocated to him for painting in oil with a palette knife the new and joyous entry which the king our lord has made in this city, ... this entry will be placed in the book of histories, as has been done previously upon the entries 
which the late kings have made in this city." ${ }^{60}$ Compiled by Toulouse's foremost dignitaries, and with paintings by local artists, these "books of histories" represented a deliberately crafted collective memory.

The material staging and recording of royal entries were inevitably moments of negotiation between the monarch's sovereign power and the city's political autonomy and civic identity. ${ }^{61}$ This can be seen in the reception the young Charles IX and his mother received upon visiting Toulouse during their tour de France in 1565. The capitouls, representatives of Toulouse's power and independence, welcomed the king in their robes of office at the gates, before symbolically handing over the city keys (fig. 6). The rhetoric of deference and submission to the king, shot through with assertions of local power and identity, continued inside the city walls. While the chronicles record original plans to erect a single triumphal arch made of marble, "to serve posterity as a witness and monument of the city's devotion," this had to be abandoned for lack of time and money. ${ }^{62}$ Instead, the city authorities opted for a remarkable feat of ephemeral production to stage the king's entry. Dominique Bertin (fl. 1551-77) and Dominique Bachelier (fl. 1565-70), Toulousain engineers and architects appointed as chief overseers, corralled the city's artisans into erecting a series of triumphal arches and other temporary structures along the processional route. ${ }^{63}$ Their splendor formed a stage for performances of music and poetry, following an iconographic program designed by the intellectual elite under the aegis of capitoul Jean-Étienne Duranti. ${ }^{64}$ The

60 "Payer a Serve Cornoailh, maistre peintre de Tholose, la somme de septante livres tournois a luy ordonnee pour peindre a huille en truelle la nouvelle et heureuse entree que le roy nostre sire a faicte en ceste ville ... icelle entree mettra dans le livre des histoires, ainsin comme se faict cy devant aux entrees que les feuz roys ont faicte en cestedite ville": Archives Municipales de Toulouse (hereafter AMT), CC2451, fol. $257^{\mathrm{r}}$.

${ }^{61}$ See, e.g., Meadow.

62 "Pour servir a la posterité de tesmoignage et monument de la devotion de la ville": AMT, BB274, chronique 240, 1563-64, 337-38; Debuiche, 2012, n.p.

${ }^{63}$ Bertin, who perhaps saw to the imitation marble in the ephemeral decorations, profited from the entry, obtaining a renewal of his royal authorization to quarry the (real) marble of the Pyrenees. In the letters patent of 1565 , Charles IX reveals with praise that Bertin had already delivered marble for the construction of the Tuileries, the project of Catherine de Médicis, for which Philibert De l'Orme had architectural responsibility. For more information on the palace's construction, see Fonkenell, 14. The king's account documents how Bertin demonstrated his knowledge of the marbles: "And when we were lately in our city of Toulouse, he [Bertin] also showed us - and the queen our lady and mother, princes of our blood, and gentlemen of our privy council—several kinds of the aforesaid marbles, stones mottled with many beautiful colors, both worked and raw": Archives départementales de la Haute-Garonne, 1B1906, fol. $225^{\mathrm{r}}$ (item 107).

${ }^{64}$ For the tradition and mode of theatricality of such staging in the realms of the French kings and Burgundian dukes, see Weigert, 31-57. 


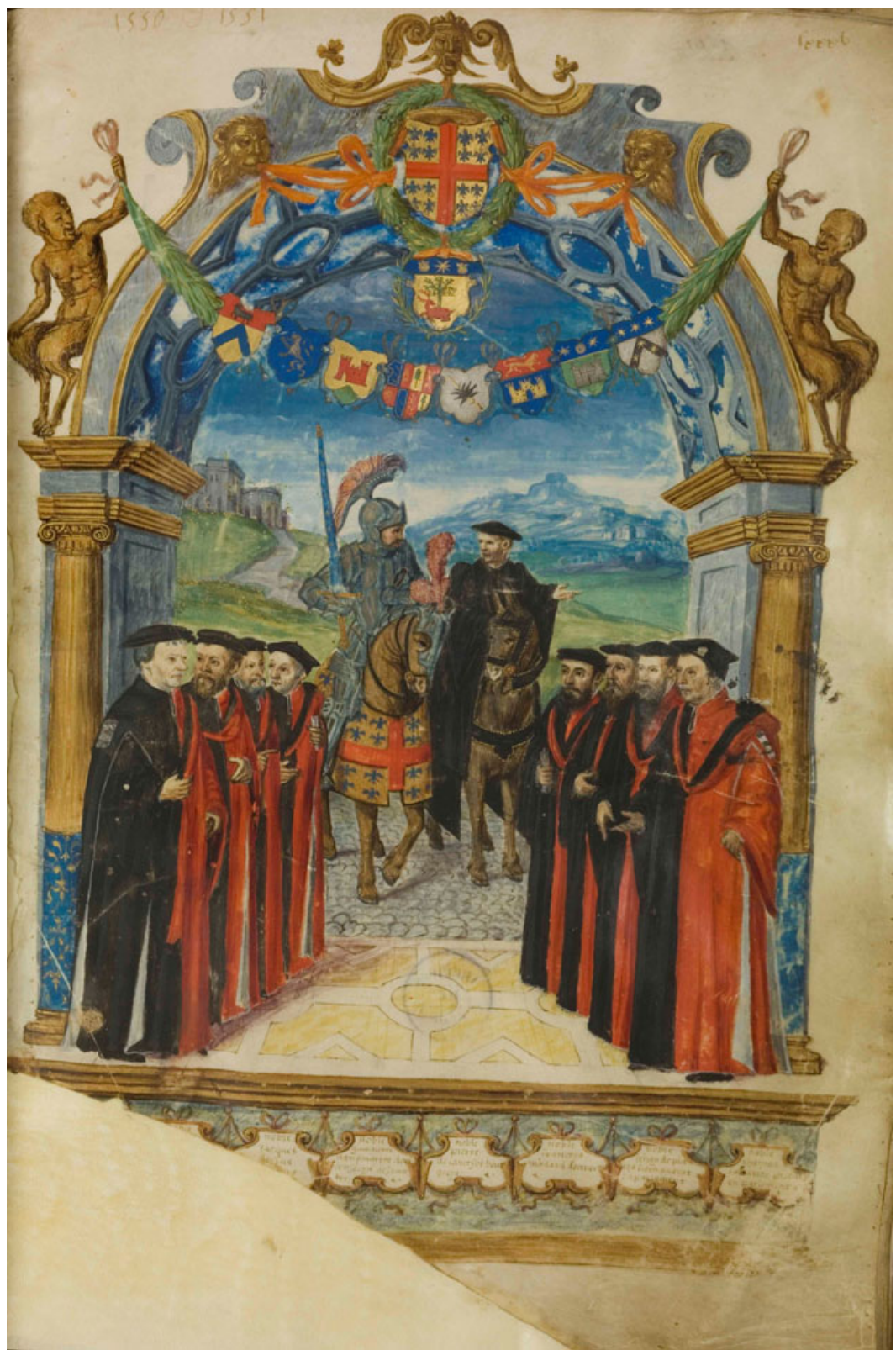

Figure 6. The Toulouse Annales. 1550 entry of Anne de Montmorency, connétable, gouverneur de Languedoc, and Jean Bertrand, garde des Sceaux, into Toulouse, with the capitouls at the city gates in their characteristic black and red garb to welcome Montmorency and Bertrand into Toulouse. Archives municipales de Toulouse, BB274, 1550-51, chronique 227, fol. $85^{\mathrm{r}}$. (C) Ville de Toulouse, Archives municipales. 


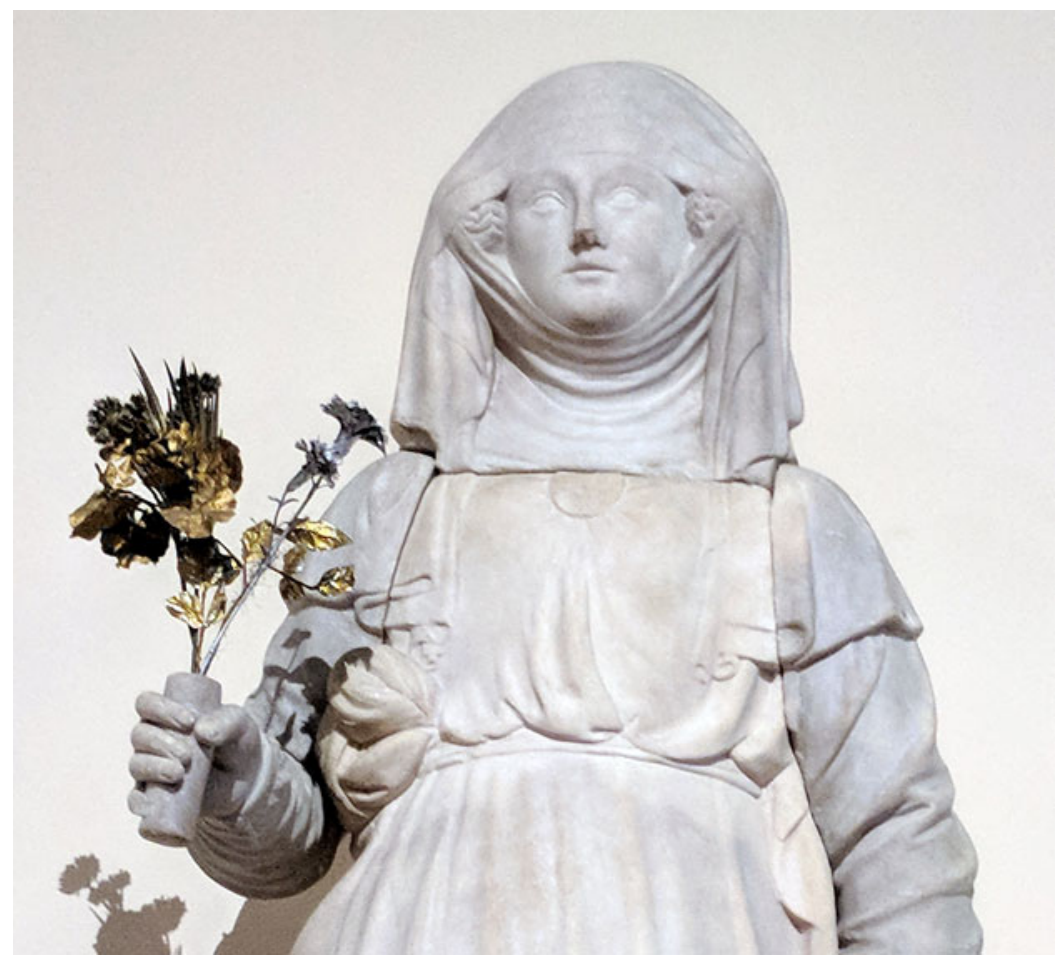

Figure 7. Medieval sculpture of Clémence Isaure with the flowers of the Jeux Floraux. Restored in 1627 by Pierre Affre. Salle Clémence Isaure, Hôtel d'Assézat, Toulouse. (C) Union of Academies of the Hôtel d'Assézat, Toulouse.

young monarch, having had little time to make his mark by great achievements, was instead feted in representations of his noble lineage and hailed as a rising beacon of hope after decades of religious unrest. In the Place de la Pierre, a temporary theater was dedicated to the nine muses (in reference to Charles IX) and to Clémence Isaure, legendary medieval foundress of the Jeux Floraux (fig. 7). Their eponymous prizes were flowers lifecast from silver, which the king received by way of an ingenious piece of machinery: "there was a great cloud from which emerged a sphere assembled with great artifice. In it was a young child dressed as a nymph, to present the said silver flowers to the king as he went by." 65 Eliding mythology, monarchy, and its thriving literary tradition, the city produced a dazzling material display of local intellectual culture and craftsmanship.

65 "Il y avoit une grande nuée, de laquelle sortoit un Globe composé de grand artifice, dans lequel il y avoit un jeune enfant habillé en Nimphe, pour présenter lesdites Fleurs d'argent au Roy en passant par là": AMT, BB274, chronique 241, 1564-65, 356. 
The "great artifice" of ephemeral production that proved the city's ancient place and privileges to its sovereign is everywhere evident in official accounts of the event. Instead of real marble, there were "columns with their bases and capitals decorated with leaves and scrolls gilt all over; the shaft of the said columns being painted the color of black-and-white marble." 66 Other columns were "colored with jasper color" and adorned with "bronze-colored figurines," or "jaspered and fluted, with gilt plinths and capitals." $" 77$ One of the arches even sported "two great silver and gold columns, twisted one around the other." 68 While gilding and painting temporary artworks to create the effect of costly materials was no doubt faster and cheaper than Bertin's planned marble arch, in fact these techniques were also employed in more permanent structures, as indicated by the columns painted to imitate jasper, marble, and alabaster, and their pediments (caissons) ornamented with roses à l'antique, in the choir of Toulouse's St. Sernin church (1536-42). ${ }^{69}$

This artifice required its own wealth of materials and workmanship, leaving ample traces—and significant expenses—in the city's account books. One "Jehan Delom, master founder in Toulouse," provided a quantity of latten (copper alloy) "for foliage for the sculptors who work on the entry of the king," likely the base for the gilt foliage mentioned in the chronicle. ${ }^{70}$ In November 1564, "Philibert Marlot, master gold- and silver-beater living in Toulouse," was paid 24 livres tournois for a thousand sheets of fine gold leaf

66 "Colonnes [ornéz] de leurs bases \& chapiteaux avec leur fueillages, \& volutes tous doréz; le tige desdites colonnes peint a couleur de marbre blanc \& noir": Lafaille, 81.

67 "Colorees de couleur de jaspe ... figures de couleur de bronze": Lafaille, 72; "jaspées \& canelees avec leurs bases \& chapiteaux doréz": Lafaille, 75.

68 "Deux grandes colonnes torses d'or $\&$ argent l'une dans l'autre": Lafaille, 79.

${ }^{69}$ Julien, 3:699, cites the following passages from archival records: "la moitié desdites colomnes jusques à terre seront painctes a couleur de jaspe" ("the bottom half of the said columns will be painted the color of jasper"), "les chapiteaulx et enbases seront de blanc à l'huile comme si était marbre ou albatre" ("the capitals and bases will be of white oil paint as if they were marble or alabaster"): Archives paroissiales de Saint-Sernin (hereafter APSS), B5, fol. 196"; "l'epaiseur de la murailhe de l'ouverture des vitres sera peinte parquetee de roses d'antique" ("the cross-section of wall in the window openings will be painted with a pattern of roses in the antique manner"): APSS, B5, fols. 195 -196"; "l'epaisseur de bas dessus lesdites colomnes sera parquetee de roses à l'antique comme est contenu au pourtraict" ("The soffit above the said columns will be covered with a pattern of roses in the antique manner as is specified in the design [i.e., the design agreed upon in the contract]"): APSS, B5, fols. 196 ${ }^{\mathrm{v}}-197^{\mathrm{r}}$.

70 "Jehan Delom, maistre fondeur en Tholose, ... troys molles de laton pour fulhages pour les sculpteurs qui travalhent pour l'entree du roy": AMT, CC2451, fol. $137^{\mathrm{r}}$ (11 October 1564). 
to be used for the royal entry. He also delivered a thousand sheets of or bel (tinsel), a lower-grade metal leaf made to look like gold. At 10 livres tournois per thousand, it was significantly cheaper than real gold leaf. ${ }^{71}$ In January 1565 , Marlot delivered another three thousand sheets of tinsel, but no gold leaf, suggesting that most of the decorations for the royal entry were made with this frugal alternative. Master painters were enlisted to "paint and gild a banner" and to produce hundreds of copies of the coats of arms of the king, the queen mother, and other dignitaries. ${ }^{72}$ Servais Cornoaille, who, as we saw, was commissioned to capture the occasion in the commemorative painting for the city's records, also joined this effort of mass production, contributing twenty-eight painted coats of arms. ${ }^{73}$ A local printer was paid for 1,500 copies of coats of arms-a scale of production suggesting their use as pennants to be distributed among the people. ${ }^{74}$ Instead of focusing on a single lasting monument, the city's artisans produced a temporary display calculated to impress by its visual abundance and cunning imitations of the effects of magnificent materials. Upon conclusion of this memorable occasion, its material products were "distributed and given to the convents and main churches of the city in dedication, remembrance, and fond memory of his majesty." 75 Like the Antwerp giant, then, these objects of ephemeral production came to embody the collective memory of the event, thus consolidating the city's claims to political power and ancient heritage.

\section{MAKING EPHEMERAL ART: SOURCES, MATERIALS, AND TECHNIQUES}

The Annales of Toulouse, like other sources such as account books, allow a glimpse of the speed and magnitude of such undertakings, as well as the large numbers of craftspeople involved. It took six months to set up the twoweek meeting of Henry VIII and Francis I in English Calais in 1520. This celebration of their amity was named the Field of the Cloth of Gold for the abundance of expensive cloth made from gilded metal-wrapped thread. Six thousand workers from both Flanders and Britain built a temporary castle

${ }^{71}$ AMT, CC2451, fol. $122^{\mathrm{r}}$ (27 November 1564).

72 "Peinct \& douré une banyere": AMT, CC2451, fol. 178 (26 January 1565).

${ }^{73}$ AMT, CC2451, fol. $141^{\mathrm{v}}$ (3 February 1565).

${ }^{74}$ As in the festivities of the d'Este court, where pennants were ordered from painters by the hundreds (Tuohy, 272-73), and in the London Lord Mayors' shows (forty pennants made of taffeta and sarcenet, for example, in the 1622 Lord Mayor's pageant). Wiggins and Richardson, 84-85.

75 "Distribuéz et donnéz aux convens et principalles eglises de ladicte ville en dedication, souvenance et bonne memoyre de sa magesté”: AMT, BB274, chronique 241, 1564-65, 377. 
structure on a brick foundation with real glass in its windows and topped by fabric tents. ${ }^{76}$ For the Greenwich revels of 1527, an entire banqueting hall, theater, and triumphal arch were built in four months, during which Hans Holbein painted a "cosmological ceiling" using at least 320 ells (ca. 400 meters) of canvas. ${ }^{77}$ Such financial accounts also include expenditures for materials, although these are less often studied by historians. ${ }^{78}$ For example, the Field of the Cloth of Gold accounts record outlay for flour, brown paper, white lead, red lead, ocher, russet, tinsel, silver, white paper, and linen, among other materials. The accounts of the Greenwich revels show that an imitation rock was made of wood and paper painted with aqueous binders such as gum, animal skin glue, and egg, while the spectator seating required oil-bound paints that took about a week to dry. Arches were made of molded paper, and six hundred stars of gilded lead were affixed to the cloth ceiling. ${ }^{79}$ For Louis XIII, who requested that his 1621 entry into Toulouse be marked by ceremonial pomp equivalent to that celebrating Charles IX in 1565, four master painters of Toulouse were paid for the "sculpture, painting, ornaments, painting of relief figures, and writing mottos and verses," 80 while the master carpenters were responsible for constructing the triumphal arches, all under the aegis of three "master architects and sculptors." ${ }^{11}$ A glass painter, Ramond Dubernet, was charged with painting 694 coats of arms of the king and queen as well as of the city (each valued at 15 sols), of which 248 were made of carton (pulped, molded paper) and gilded with tinsel or silver, and 446 were made with "common paints and colors" (worth 7 sols each). ${ }^{82}$

The rare surviving objects from ephemeral events, such as the head of the giant of Antwerp, banners from military and church processions, or the polychromed wooden jousting Saracen made for the 1579 wedding of Medici Grand Duke Francesco I and Bianca Cappello, allow insight into the historical materials used; however, the objects' surface layers are complicated by their

${ }^{76}$ For accounts of the building of the Field of the Cloth of Gold, see British Library, Cotton MS Augustus 111, fol. 18, tent designs for the Field of the Cloth of Gold, ca. 1520; National Archives, Kew, E36/229, accounts of Richard Gibson for revels (connected with the Field of the Cloth of Gold), 22 April 1520-21 April 1521. With thanks to Jo Kirby.

${ }^{77}$ Brewer, nos. 3097, 3098, 3104, 3107. With thanks to Jo Kirby.

${ }^{78}$ Notable exceptions include the essays in Cannon et al.; see, specifically, Nash.

${ }^{79}$ Foister, 110-15. With thanks to Jo Kirby.

80 "La sculteure, la plate peincture, ornemens, peincture des figures de relief, escripture des devises \& vers": AMT, CC2621, items 82 and 106. The sculpture was likely stucco. See Alard for a description of the entry.

${ }^{81}$ AMT, CC2621, items 90 and 104.

${ }^{82}$ AMT, CC2621, item 211. 
continued reuse and refreshing up until the nineteenth century. ${ }^{83}$ Household objects made from so-called temporary materials, such as Jacopo Sansovino's (1486-1570) dozens of painted cartapesta (pulped and molded paper) niche reliefs of the Madonna and Child likely intended for domestic devotion, form another relevant source for understanding the craft of ephemeral art (fig. 8). Such objects need to be examined in conjunction with written chronicles of the festivals, account books, and technical accounts of making processes. Such accounts, including technical texts, are more numerous than suspected by most historians and can be found in even the best-known art historical sources. In the life of Jacopo della Quercia (ca. 1367-1438), Vasari celebrates the artistic innovation and experiment involved in using such materials: an oversized commemorative sculpture employed "a method of making the skeletons of the horse and of the figure which had never been used up to that time-namely, with pieces of wood and planking fastened together, and then swathed round with hay, tow, and ropes, the whole being bound firmly together; and over all there was spread clay mixed with paste, glue, and shearings of woolen cloth. This method, truly, was and still is better than any other for such things, for, although the works that are made in this fashion have the appearance of weight, none the less after they are finished and dried they turn out light, and, being covered with white, look like marble and are very lovely to the eye." 84 Not just innovative, such lightweight sculpture was also more durable, and, as Vasari notes, does not crack as it dries. Vasari suggests the central role of decorative and festival art in bringing about what art historians have come to regard as the main supports in the high visual arts - fresco and canvas. Vasari views both as having emerged out of the practices of ornamenting house facades and festival art: "artists have been accustomed to decorate in monochrome the facades of palaces and houses, giving these a semblance other than the reality, and making them appear to be built of marble or stone, with the decorative groups actually carved in relief; or indeed they may imitate particular sorts of marble, and porphyry, serpentine, and red and gray granite or other stones, or bronze, according to their taste." Such ornamentation is done by fresco, Vasari continues, the "true way," or on canvas "intended for arches, plays, or festivals." ${ }^{25}$ An early example of such wall painting is extant today in the paintings of the vaults, tribunes, and chapels of the cathedral of Albi (1509-20), near Toulouse. ${ }^{86}$

${ }^{83}$ Saracen jousting figure, 1579, polychrome wood, $202 \mathrm{~cm}$ x $80 \mathrm{~cm}$ x $50 \mathrm{~cm}$, Florentine, Museo Nazionale del Bargello, Florence. See Lasansky, 147-52; Kumar, 163, 174-75.

${ }^{84}$ Vasari, 1912-15, 2:91-92.

${ }^{85}$ Vasari, 1907, 240-42.

${ }^{86}$ On the political and iconographic program of the Albi paintings, see Gaggetta. 


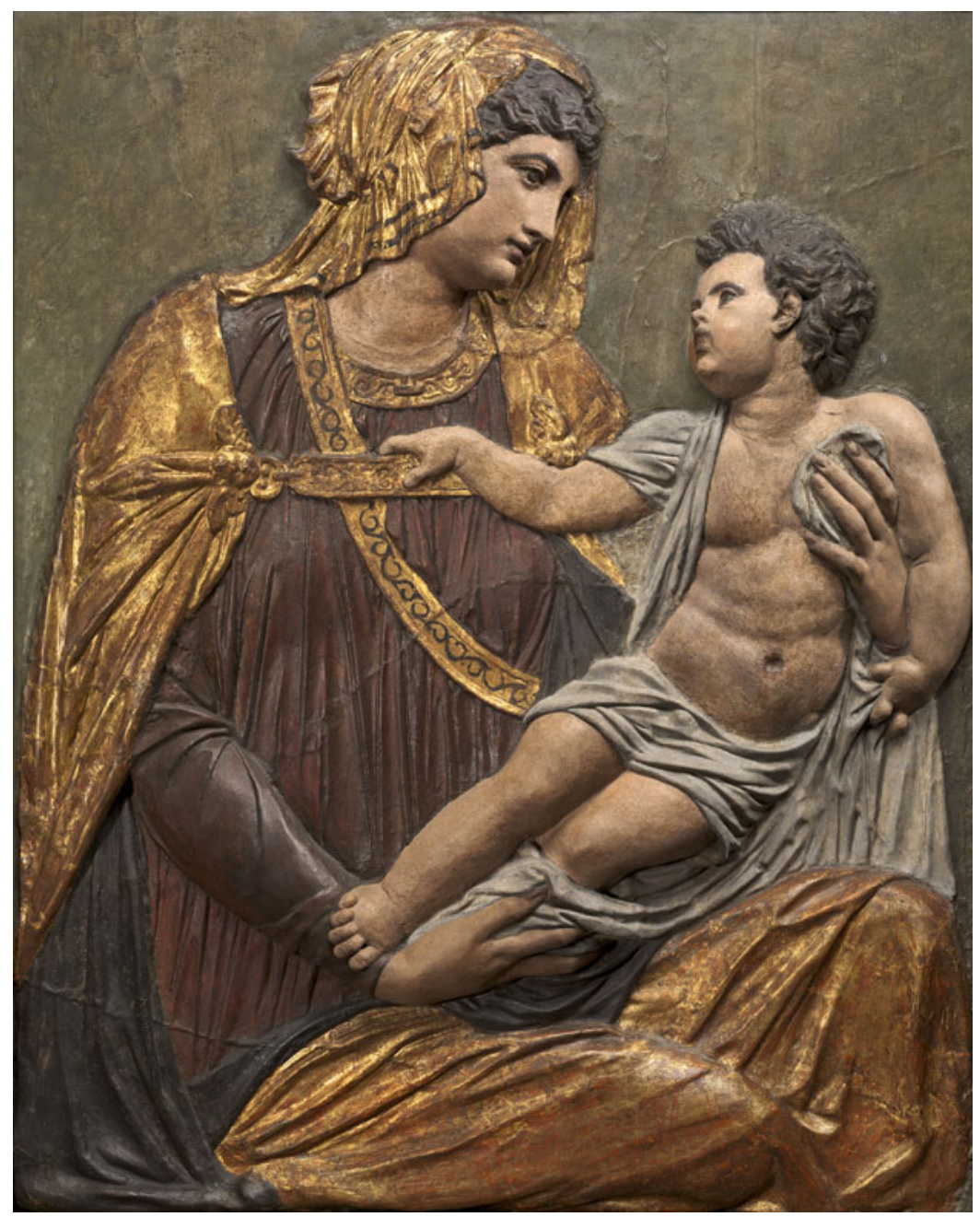

Figure 8. Jacopo Sansovino. Madonna and Child, ca. 1550, formed from papier-mâché (likely molded paper pulp) and stucco, then painted and gilded. Samuel H. Kress Collection, 1961.1.6. Courtesy National Gallery of Art, Washington, DC.

A lesser-known source for the making of ephemeral art is BnF MS Fr. 640, compiled in Toulouse in the late sixteenth century, now being investigated by the Making and Knowing Project at Columbia University. ${ }^{87}$ This manuscript

${ }^{87}$ For more information on the project, see the Making and Knowing Project: www.making andknowing.org. For the digital critical edition, see http://edition640.makingandknow ing.org. 
contains instructions, in many cases apparently tested by the anonymous author-practitioner, for many of the elements of ephemeral displays treated so far in this article: stones that imitate marble, jasper, carnelian, and precious gems, expensive materials imitated by less costly and labor-intensive versions, among which are "damasked cloth," vitreous rouge clair (red glass enamel over gold leaf) imitated in pigment and oil, or bel or tinsel (gold leaf imitated by yellow-colored varnish on silver leaf, as used in great quantity for the entry of Charles IX into Toulouse, described above), lightweight architectural elements made of molded paper, fast-drying stucco, rocks made from heated parchment, flowers and animals preserved by life casting and by drying, painted cloth to be carried outdoors, dyeing animals (perhaps similar to the horses disguised as lions, unicorns, or dragons in Ferrara), and many other techniques. ${ }^{88}$ This list could be much extended, but rather than treating the reader to a simple recapitulation of these recipes, the remainder of this article will show that the manuscript's processes for the making of ephemeral art possess aims, materials, and techniques identical to those now considered separate categories of nonephemeral high art. We strive thereby to question art historical frameworks, categories, and hierarchies that have informed much of the discussion of ephemeral, decorative, and related categories of artworks.

\section{Decorative Art: Making the Ephemeral Last}

A handful of recipes in BnF MS Fr. 640 seem explicitly intended for festive events, such as "For dyeing [an animal]," "Fruit made from sugar," and "Impromptu mask." 89 The manuscript serves more powerfully, however, to problematize the ephemeral as a distinct category of art making, for many of the materials, techniques, and intended effects of these ephemeral displays were also put to work in the production of what art historians might now term decorative arts, such as plaster reliefs to embellish domestic space, ${ }^{90}$ imitation materials used to decorate inlaid furniture, ${ }^{91}$ and techniques to produce ornamented caskets or chests. ${ }^{92}$ While these objects might not have been expected to survive in perpetuity, they were certainly intended to last longer than a single triumphal entry or pageant. With their clever techniques and innovative use of imitation materials, such objects are examples of the kinds of new and affordable luxuries being consumed not by the most wealthy elites but by the upwardly mobile middle classes, such as successful urban craftspeople and

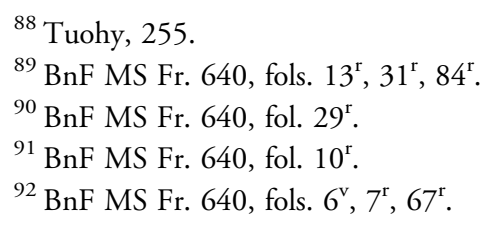


the lesser gentry. ${ }^{93}$ These kinds of objects tend not to survive in museum collections, as they were not made of the finest materials, nor do they have connections to famous owners or makers. Thus, they might be said to take on an ephemeral identity less connected to their use in short-term display than to their status as objects that have not been preserved or collected. Nevertheless, their inclusion in early modern art writings signals their importance as works of art.

Artists drew explicit connections between the skills necessary to produce "great" and "small" art and to work monumental and humble materials. The Italian painter Cennino Cennini (ca. 1360-ca. 1427), for example, encouraged artists to experiment with various techniques when decorating caskets or chests. While an artist might gild, stamp, and embellish a chest "royally," Cennini also offered suggestions for those who "want to execute other caskets of less worth" with cloth, gesso, and figures of tin and tinfoil shaped like "flowers, stars, roses, and any kind your mind [intelletto] desires." Cennini expected that a skilled artist would be able to adapt their talents from elite art to more cheaply made objects, explicitly stating, "if you are really expert and practiced in great things, you will know well how to do small ones." ${ }^{4}$ Vasari, too, expected artists to adapt their talents and processes from fine arts to more affordable ones. "Great skill in design," he wrote of sculpting in low and half relief, "is necessary if the artist wishes to exhibit his ability in this art. The same degree of perfection is demanded for figures in clay or wax as for those worked in bronze or marble." Regardless of its material composition, a well-executed half relief, he claimed, may be considered "most beautiful and most highly praised by experienced artists." Vasari traced the origins of sculpted figural reliefs back to an ancient domestic context, claiming that they were used "to adorn flat walls," noting that the technique had been "adopted ... in theatres and triumphal arches." 95 Later, in a discussion of white stucco, Vasari stressed the permanence of plaster reliefs: "Nor is one to suspect work so done of being perishable; on the contrary it lasts forever, and hardens so well as time goes on, that it becomes like marble." 96 Similarly, BnF MS Fr. 640 describes decorative molding techniques that could be used either in a modest domestic setting or a large-scale ephemeral

${ }^{93}$ The literature on social status and material culture has burgeoned, but foundational texts include Goldthwaite; O’Malley and Welch; de Vries; Avery et al.

94 "Perche sesarai bene sperto epra / ticho nelle chose grandi saprai ben fare in nelle picciole dimonstran": quoted in Broecke, 221-24. This translation draws from both Broecke's translation and that of Daniel V. Thompson (see Cennini, 110), with small modifications by the authors.

${ }^{95}$ Vasari, 1907, 154-55.

${ }^{96}$ Vasari, 1907, 172. 
context. For example, the author-practitioner offers a recipe to make stucco using rye flour or chalk with tragacanth gum "to make an ornament at little expense" which could decorate both round and flat surfaces (fig. 9). ${ }^{97}$ He offers examples of purposes that could have been employed for triumphal entries or festivals, such as to making masks or garlands which "will be dry within one day," and so implies that his reader might need to execute such processes quickly, as was often the case in the production of triumphal entries. But he also envisages a long-term domestic use: in Rome, he explains, "one makes ceiling ornaments with it," and "one can make bed ornaments with it." 98

Stucco's character as quick-drying, cheap, and white meant it was used widely in the early modern period. In 1529, for example, a Doric-style triumphal arch made of stucco, decorated with scenes from the Old Testament, was erected along the processional route to the Piazza Maggiore when Pope Clement VII traveled to Bologna to meet with Emperor Charles V. ${ }^{99}$ Stucco was used as a sculpting material by Gianlorenzo Bernini (1598-1680), who created stucco angels for the catafalque that marked the first anniversary of Pope Paul V's death in January 1622. ${ }^{100}$ Stucco was also used to make copies of works fashioned in finer materials, for example a mid-fifteenth-century stucco copy of Donatello's marble Virgin and Child (ca. 1425-30). ${ }^{101}$ These examples, along with Vasari's comments, and the stucco recipe in BnF MS Fr. 640, help to complicate the category of ephemeral art by emphasizing its counterintuitive characteristics - like the durability of its finished products, the value of materials used, and the adaptability of its techniques both to small-scale decorative objects and large festival structures - and by underscoring the overall artistic value and merit of such productions at the time they were made.

${ }^{97}$ BnF MS Fr. 640, fol. $29^{\mathrm{r}}$.

98 "Take tragacanth gum and put it to soak until, having drunk its water, it is swollen $\&$ rendered like jelly. Then crush it quite hard on marble $\&$ next take rye flour, which is better than wheat because it is more humid and does not make the paste as brittle, and sprinkle your tragacanth gum with it, continue to grind $\&$ mix in thus, little by little, the very finely sieved flour. And knead it as if you wanted to make bread, until you perceive that it has enough body $\&$ is as firm as bread dough that one is ready to put in the oven": BnF MS Fr. 640, fol. $29^{\mathrm{r}}$. As discussed in Nina Elizondo-Garza, "Stucco for Molding," in Making and Knowing et al. For the use of stucco in Rome, see Kummer.

${ }^{99}$ Drogin, 280. Cited in Elizondo-Garza, "Stucco for Molding," in Making and Knowing et al.

${ }^{100}$ Montagu, 180. As treated in Elizondo-Garza, "Stucco for Molding," in Making and Knowing et al.

${ }^{101}$ Virgin and Child, after an original by Donatello, stucco and colored glass, Metropolitan Museum of Art, 22.16.3: https://metmuseum.org/art/collection/search/194856. The Staatliche Museen zu Berlin hold the marble original, known as the Pazzi Madonna. 


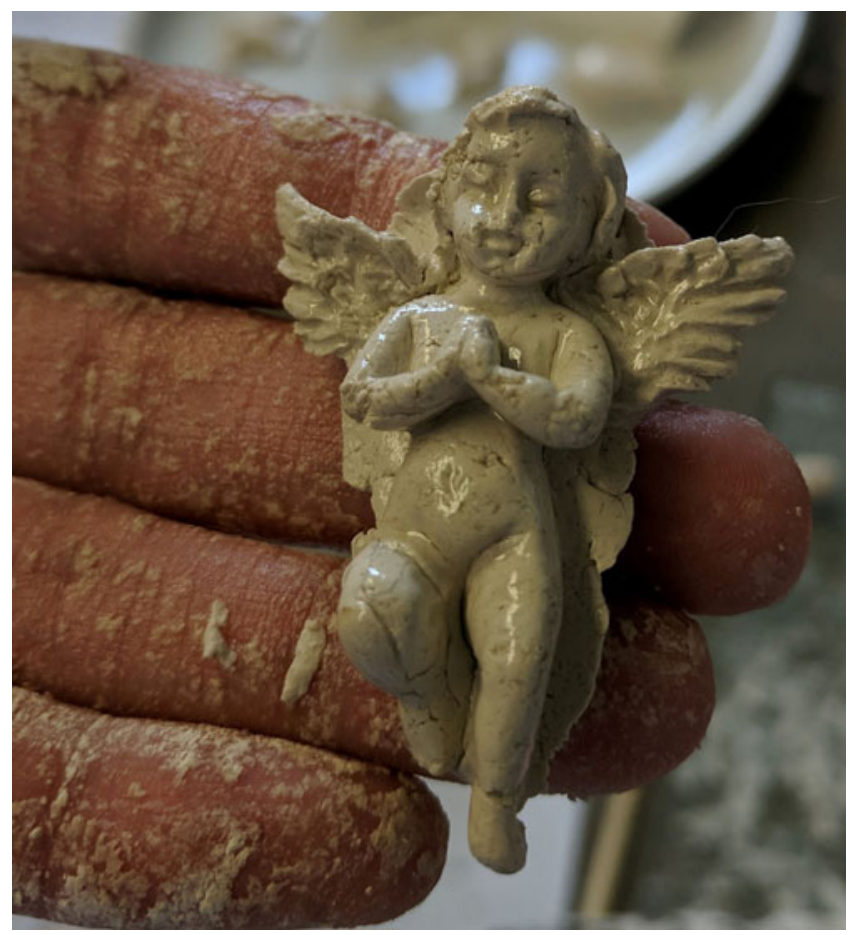

Figure 9. Stucco of tragacanth gum and chalk, made following instructions in BnF MS Fr. 640, fol. $29^{\mathrm{r}}$. Nina Elizondo-Garza, The Making and Knowing Lab, 2017. (C) Making and Knowing Project.

Stucco is not the only material in BnF MS Fr. 640 that could be used across the spectrum from triumphal arches to beds. Jaspered columns featured in the Toulouse entry of Charles IX in 1565, but an entry entitled "Counterfeit Jasper" shows how imitation materials might also be put to use in smaller-scale objects intended for a domestic context (fig. 10). ${ }^{102}$ The author-practitioner instructs the reader to apply pigments, varnish, and spike lavender oil to a thin piece of horn, which has "a luster $\&$ fatty polish like jasper." This can be further embellished, "to better counterfeit mottled jasper," with the application of dyed wool and gold or silver leaf. In a marginal note, the author-practitioner offers a possible use for this counterfeit jasper: "You can encrust beds with it" (fig. 11). ${ }^{103}$

${ }^{102}$ Temporary structures assembled for the entry of Louis XIV into Paris were built of canvas, wood, and plaster and were painted to imitate jasper as well as marble, porphyry, and precious metals. Tierney, 148.

${ }^{103}$ BnF MS Fr. 640, fol. $10^{\mathrm{r}}$, treated in Ana Estrades with Wenrui Zhao, "Counterfeit Jasper," in Making and Knowing et al. 




Figure 10. BnF MS Fr. 640, fol. $10^{\mathrm{r}}$, with the recipe Jaspe contrefaict (counterfeit jasper). Bibliothèque nationale de France, Paris. Source: gallica.bnf.fr. Public domain. 

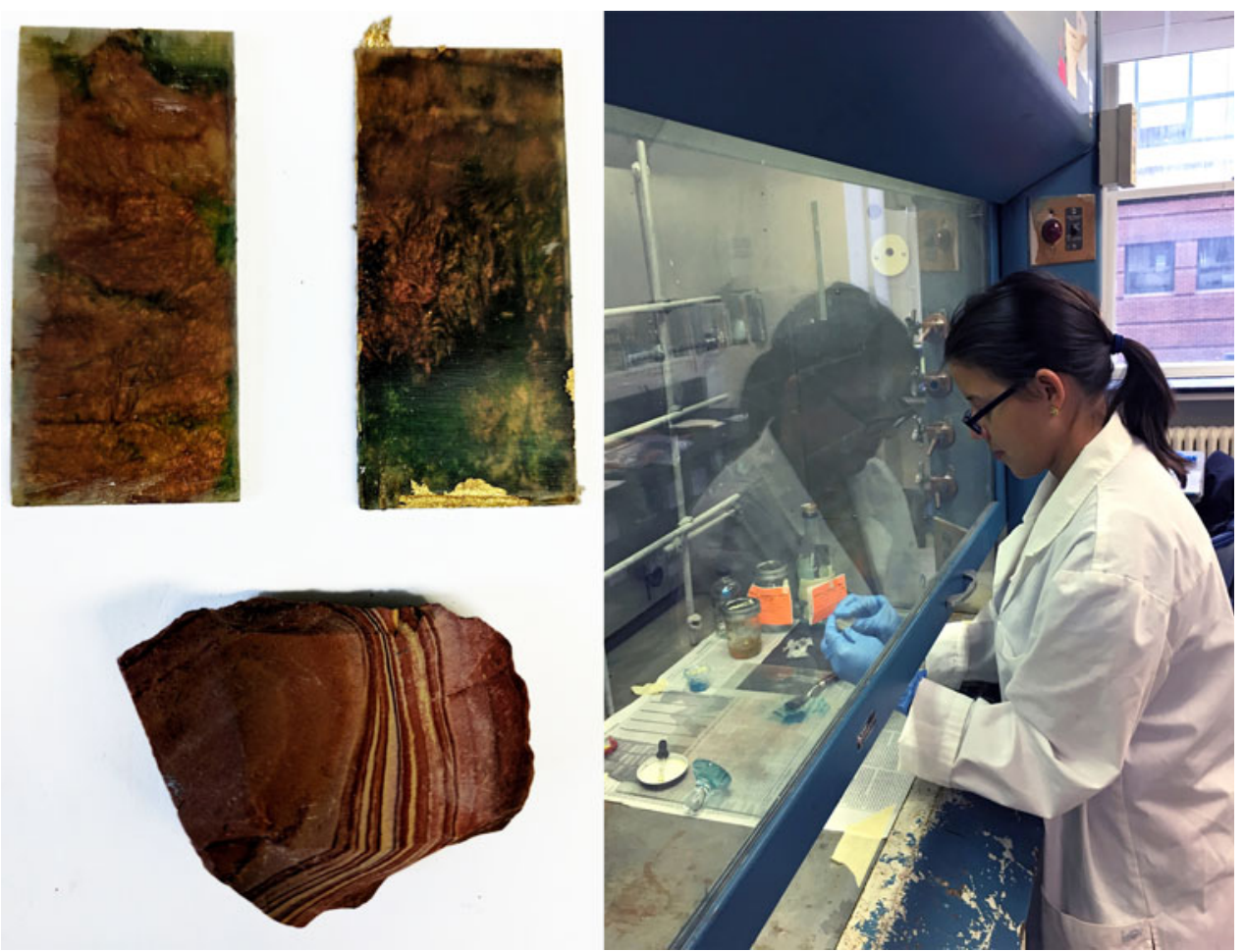

Figure 11. Jaspe contrefaict (counterfeit jasper), made following instructions in BnF MS Fr. 640, fol. 10 ${ }^{\mathrm{r}}$. Right: Isabella Lores-Chavez making counterfeit jasper, The Making and Knowing Lab, 2016; left: counterfeit jasper (top) made in the Making and Knowing Lab, compared to naturally occurring jasper (bottom). (C) Making and Knowing Project. 
While nothing dictates that such techniques could not also be employed in the creation of triumphal arches or ephemeral displays-like the jaspered columns erected for the entry of Charles IX-it is clear that the desire and practice of crafting imitation or counterfeit materials was a preoccupation for artisans, whether they were creating small decorative domestic objects or large-scale temporary structures.

The author-practitioner also exploits the properties of paper, crushed, soaked, and made into what he calls carton, to quickly and cheaply construct lightweight objects suitable for both interior domestic or outdoor festive spaces. As we have already seen, paper arches were constructed at the Field of the Cloth of Gold, but BnF MS Fr. 640 suggests using carton both as a material with which to construct "fanciful tables" and other molded figures and also as a means by which patterns could be taken off stone reliefs. ${ }^{104}$ The various ways paper might be put to use are more expansively described by the writer and inventor Hugh Plat (1552-1608). In his chapter on "The Art of Molding and Casting," Plat describes "special uses of this art," mentioning that an artist "may cast many rare and excellent patterns ... with the pap of common paper, being well wrought and laboured by a workman." He recommends such casts "to garnish beds, tables, court-cupboards, the jawms [jambs] and mantle trees of chimneys, and other stately furnitures of chambers or galleries," noting that one may, "with smal cost, cast off whole borders for chambers or galleries." Plat explains that this material "would endure no weather, yet they will serve sufficiently within dores, so as they be kept dry." 105 Paper and carton are ephemeral in the sense that they only last a short time if exposed to rain outdoors, but the properties that make them suitable for use in short-term productions like triumphal arches (they are quick and relatively cheap to produce, lightweight, and transportable) could also be successfully exploited in the production of inexpensive indoor decorative objects that would last if kept dry. Noticing that carton can "turn limp in wet weather," the author-practitioner even suggests permeating it with melted clear resin, showing how the ephemeral could be made durable. ${ }^{106}$

Another connection between decorative interior furnishings and exterior displays, and a clear illustration of how a technique might be deployed across a range of materials, can be found in instructions for "varnish on paper." In this entry, the author-practitioner explains that "the Germans make boxes covered with painted paper $\&$ varnish it with glair [white] of egg mixed with gum $\&$ a little oil, not of spike lavender, but another fragrant one that resembles olive

\footnotetext{
${ }^{104}$ BnF MS Fr. 640, fols. $68^{\mathrm{r}}, 81^{\mathrm{r}}, 80^{\mathrm{v}}, 86^{\mathrm{v}}$.

${ }^{105}$ Plat, $210-11$.

${ }^{106}$ BnF MS Fr. 640, fol. $57^{\mathrm{v}}$.
} 
oil. Every work done with glair supports oil. It is with this that painters trick the poor peasants, painting their bands of taffeta with this glair, to be done sooner. But the first rain carries away everything." 107 The use of glair, gum, and oil to varnish paper-covered boxes, and to paint on textiles, shows how one technique might transfer across a range of crafted objects intended for both interior and outdoor use. While naïve buyers might have been temporarily fooled by painted taffeta bands, which ran at the first drops of rain, the need to keep paint from running on textiles was evidently a preoccupation of the author-practitioner, who also provided instructions for a "varnish resistant to water": "Flanders varnish, made with turpentine $\&$ oil of turpentine or mastic, can come off and does not hold up in the rain. But that made with white walnut oil, as you have done, holds in the rain and is very clear $\&$ beautiful $\&$ dries soon. This is why one uses this one for painted banners $\&$ signs that one carries in the rain." 108 Such painted banners and signs were carried in guild processions and at triumphal entries, as for the 1565 entry of Charles IX into Toulouse, where master painter Arnaud Arnauld was paid 15 livres for his painting and gilding of a banner and pennant. ${ }^{109}$ Other artists seem to have specialized in this work, such as Agnes van den Bossche, who painted flags, pennants, and canopies for the city of Ghent and its guilds in the 1470s and 1480s. ${ }^{110}$ Other BnF MS Fr. 640 entries describe methods to paint in oil on taffeta "without the oil running," apparently in order to stop oil paint from bleeding or seeping through onto the reverse of a textile, so that it could be displayed on both sides (as a banner carried in a procession would have been). ${ }^{111}$ The desire for rain-proof techniques also links domestic decoration to ephemeral productions, as processes such as painting gold in distemper would be "undone in the rain" while the technique of gilding with gold color and tinsel "will hold up in the rain on houses \& elsewhere." 112

${ }^{107}$ BnF MS Fr. 640, fol. $67^{\mathrm{r}}$.

${ }^{108}$ BnF MS Fr. 640, fol. $31^{\mathrm{r}}$. On fol. $3^{\mathrm{r}}$ he also mentions in a marginal note that "mastic varnish does not resist rain, whereas that of oil and rosin does." For another recipe for a "permanent" varnish, see Neven, 136-37, recipe 97.

${ }^{109}$ AMT, CC2451, fol. $178^{\mathrm{v}}$ (26 January 1565).

${ }^{110}$ Wolfthal.

${ }^{111}$ BnF MS Fr. 640, fols. 10 ${ }^{\mathrm{v}}$, 42 . See Tianhe Lou and Marilyn Bowen, "For Painting in Oil on Taffeta without the Oil Running" and "Oil Painting on Taffeta," and Summeye Yar, "Oil Painting on Taffeta," in Making and Knowing et al. See also the short research film by Sophie Pitman and Summeye Yar, "Oil on Taffeta": https://youtu.be/iNHnZ31toZo. One of the few names of Toulouse inhabitants mentioned in BnF MS Fr. 640, the heirs of Benoit Ouvrier, wealthy merchants supplying the capitouls, provided taffeta for the banners of the "capitoulat de Saint-Barthélémy" and "capitoulat de Saint-Sernin" in 1589: AMT, CC1986, fols. $12^{\mathrm{v}}, 15^{\mathrm{r}}$. With thanks to Sarah Muñoz for this information about the Ouvrier.

${ }^{112}$ BnF MS Fr. 640, fols. $32^{\mathrm{r}}, 7^{\mathrm{r}}$. 
As the author-practitioner's statement suggests, gilding techniques might be used to decorate a house, or could have been used in any other temporary external structure, such as a triumphal arch.

Other techniques also resist being categorized exclusively as ephemeral art. While adding quicksilver to powder can give "force to fireworks" for a festival or celebration, it is also a means for "bursting grenades," and so is a technique that could be employed in celebrations and warfare alike. ${ }^{113}$ The way a sheathmaker produces small leather works by dampening small skins and spreading fuller's earth on them, before placing them under a press to dry, then applying black copperas and iron scale, and finally reinforcing it with fabric on the reverse, could also be used to "quickly imitate big statues ... [that] are light and portable and last for a long time." 114 The affordances of skin-its ability to be molded, dried, and easily transported-were also exploited in the manuscript's entries for "grottos," in which "to fill some empty place [in the grotto] that cannot be laden with some sort of hanging rock, one puts a piece of thick parchment close to the fire, which shrinks \& crumples. Then one paints it with distemper, then in oil" (fig. 12). ${ }^{115}$ Such a technique may have been useful for imitating the rocks in Rubens's Arch of the Mint (1635) that contained multiple depictions of the rocky crags and caves of the silver mountain of Potosí, a part of the 1635 entry into Antwerp of the Cardinal-Infante Ferdinand (fig. 1). ${ }^{116}$ The author-practitioner took great interest in imitating the effects of more costly materials with cheaper substitutes, often with time-saving techniques, providing recipes for a variety of surface finishes, including imitation bronze to decorate wooden candlesticks and gilding with gold color and tinsel. ${ }^{17} \mathrm{He}$ provided recipes for "gold without gold on silver," and metal finishes on wood, as well as substitution objects, such as molded paper to imitate alabaster; imitation damask as "cheap embroidery"; sugar casts of molded fruit; and imitation emeralds, rubies, topaz, and diamonds made of colored glass (fig. 13). ${ }^{118}$

As the preceding section shows, skills and materials associated with shortlived public displays should not be seen as confined to a category of ephemeral

${ }^{113}$ BnF MS Fr. 640, fol. $8^{\mathrm{r}}$.

${ }^{114}$ BnF MS Fr. 640, fol. $57^{\mathrm{v}}$.

${ }^{115}$ BnF MS Fr. 640, fols. $40^{\mathrm{r}}, 118^{\mathrm{r}}$.

${ }^{116}$ See McGrath for a discussion of Rubens's designs and iconography; her discussion does not include his techniques of execution.

${ }^{117}$ BnF MS Fr. 640, fols. $5^{\mathrm{v}}, 7^{\mathrm{r}}$.

${ }^{118}$ BnF MS Fr. 640, fols. $29^{\mathrm{v},} 7^{\mathrm{v}}, 12^{\mathrm{r}}, 15^{\mathrm{r}}, 31^{\mathrm{r}}, 2^{\mathrm{v}}, 99^{\mathrm{v}}, 100^{\mathrm{r}-\mathrm{v}}, 138^{\mathrm{v}}$. "The same dose is observed for all gemstones, namely one weight of calcined pebbles on three of minium, pestling all separately in a copper mortar for emerald, $\&$ in an iron mortar for making topaz or amber color, with pestles identical to the mortars. The emerald $\&$ the topaz are of the same heat, $\&$ for an hour \& a half on the fire, for they could burn": BnF MS Fr. 640, fol. $101^{\mathrm{r}}$. 


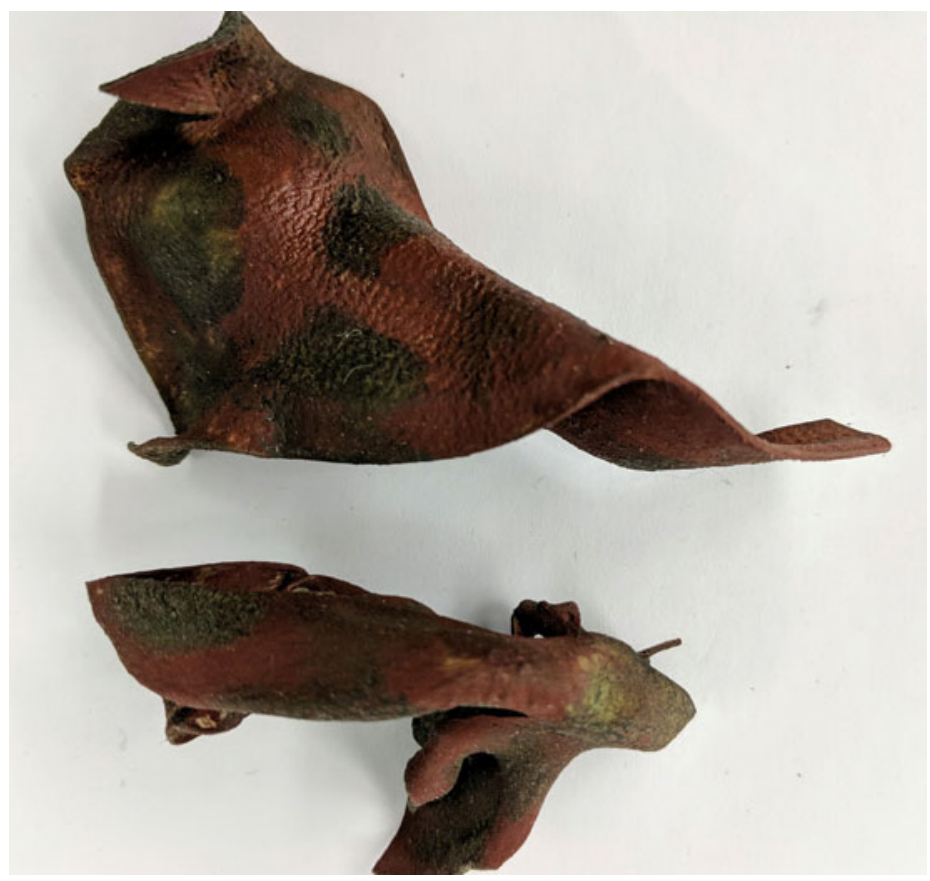

Figure 12. Rocks for grottos, made following instructions in BnF MS Fr. 640, fol. $40^{\mathrm{r}}$ : "Grottos. To fill some empty place that cannot be laden with some sort of hanging rocks, one puts a piece of thick parchment close to the fire, which shrinks \& crumples. Then one paints it with distemper, then in oil. Next one affixes it." Reut Ullman, The Making and Knowing Lab, 2017. (C) Making and Knowing Project.

art. Given the many artists (celebrated and lesser known) who worked on these commissions, it is not surprising that the affordable and quick techniques described above were also used in the production of objects for elite and nonelite consumption. Further, the material and technical lens complicates our understanding of the impact of ephemeral works. The spectacular nature of short-lived displays may have impressed large numbers of audience members, but cheap works like painted paper boxes could have been consumed by an equally large number of people in modest settings. Such widespread but humble objects may have resulted in a broader impact on the aesthetic imagination of the early modern viewer than the objects usually found in elite Renaissance collections, such as cabinet paintings, bronze and alabaster statuettes, finely wrought jewelry, tableware of silver and gold, or carved marble mantles, which were enjoyed by only a fortunate few. A text like BnF MS Fr. 640, and a focus on materials and making, thus necessarily prompts us to reevaluate the boundaries of the term ephemeral art. What, exactly, do we mean by the 


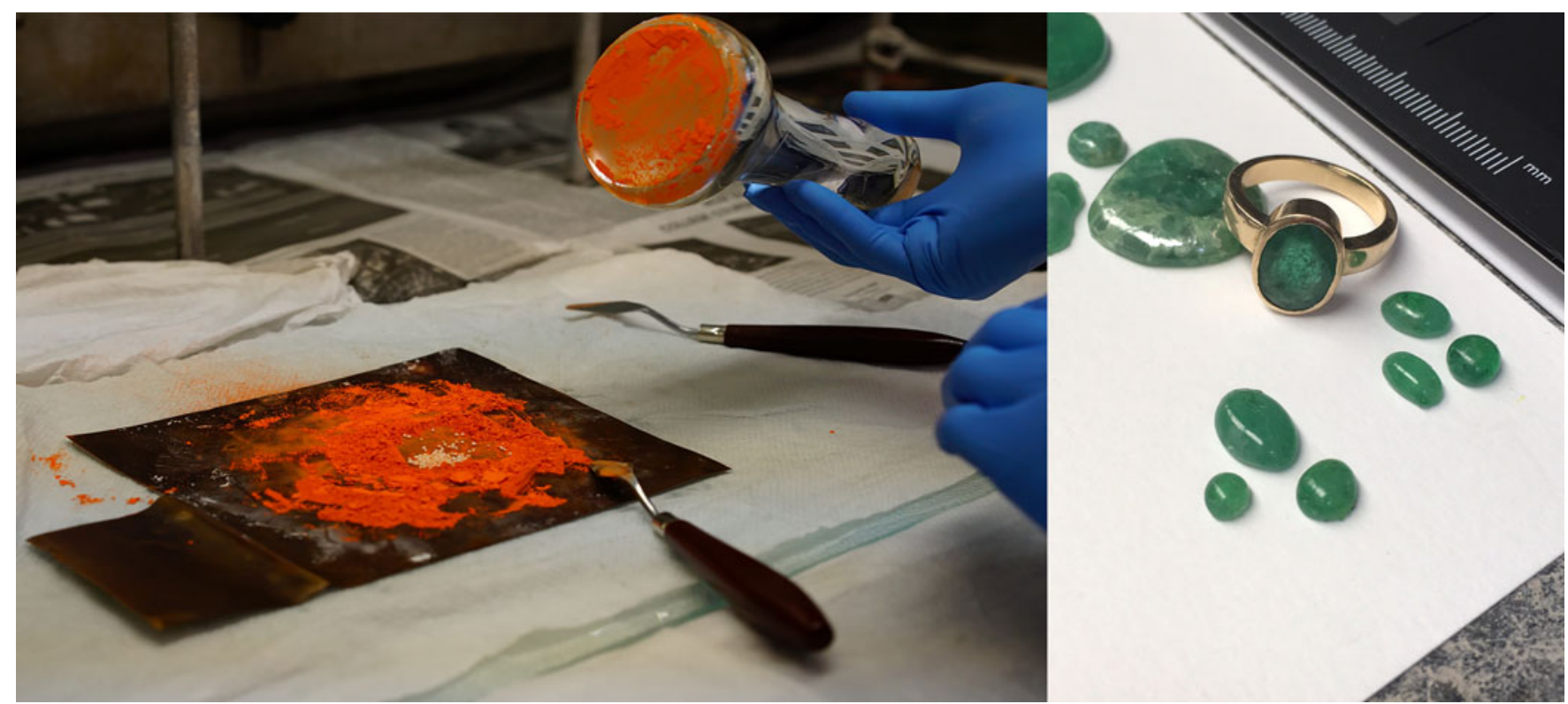

Figure 13. Pierreries (gems), made following instructions in BnF MS Fr. 640, fol. $100^{\mathrm{r}-\mathrm{v}}$. Esmeraulde (emerald). Images show the transformation of ground quartz, red lead, potash, and copper (left) into imitation emeralds (right). Kathryn Kremnitzer and Siddhartha Shah, The Making and Knowing Lab, 2016. The emerald in the ring is authentic; all others are counterfeit. (C) Making and Knowing Project. 
term ephemeral? Three further categories of making elucidated by BnF MS Fr. 640 make this problematic question all the more urgent: can a category like ephemeral art productively account for the intermediary processes of workshop practice, for the performative transformation of materials outside the workshop confines, and for the preservation of natural ephemera themselves?

\section{Intermediary Processes and Materials}

If some of the materials and products of the early modern artist can be considered ephemeral for either their intended temporary use or their limited longterm survival, then we might also consider ephemeral those intermediary processes-impermanent by design —involved in artistic work. By intermediary processes, we refer to stages in the execution of a work of art that make instrumental use of common materials or techniques, whether to assist in specifics of making or to provide feedback on the development of a work. These materials are then discarded or destroyed in succeeding stages of making and thus leave little to no perceptible trace in the finished object. The study of a technical document like BnF MS Fr. 640 affords scholars the opportunity to recover some of these processes and thereby the attitudes of experimentation and improvisation of artists and their modes of working materials.

The clearest intermediary technique in the manuscript is what we might call breadmolding, a quintessentially ephemeral process that involves using the warm pith of freshly baked bread to quickly take an impression of an object that one is preparing to cast in more expensive, durable, and difficult-tomanipulate materials such as tin, lead, silver, or gold. ${ }^{119}$ Once the impressed bread has cooled and hardened, molten wax or sulfur is poured into the breadmold to give a cheap, easy, and effective sense of how well the original object might be reproduced; if that object is under production itself, breadmolding allows an artist to try out variations before committing to a final design. The process could also be used to hasten the casting of copies of metal reliefs, such as medals, in gold, silver, or other precious metals. ${ }^{120}$ Drawing on bread's property of being pliable when moist but then shrinking and hardening when dry, the author-practitioner also suggests breadmolding as a way to shrink a larger object or vary the shape. ${ }^{121}$

${ }^{119}$ BnF MS Fr. 640, fols. $140^{\mathrm{v}}, 156^{\mathrm{r}}$.

${ }^{120}$ BnF MS Fr. 640, fol. $156^{\mathrm{r}}$.

${ }^{121}$ BnF MS Fr. 640, fol. 140v: "Mold it with bread pith coming from the oven, or as the aforesaid, $\&$ in drying out it will shrink $\&$ consequently the medal that you will cast in it. You can, by this means, by elongating and widening the imprinted bread pith, vary the figure $\&$ with one image make many various ones. Bread coming from the oven is better. And the one that is reheated twice retracts more. You can cast sulfur without leaving the imprint of the bread to dry, if you want to mold as big as it is. But if you want to let it shrink, make it dry, either more or less." See Min Lim, "To Shrink an Object," in Making and Knowing et al. 
Testing a pattern in fresh bread appears to be uniquely recorded in BnF MS Fr. 640 , and it offers a more improvisatory and efficient solution than similar techniques described elsewhere-for instance, Vasari's suggestion to cast wax into a plaster mold. ${ }^{122}$ Breadmolding produces intermediary objectsbreadmolds and casts in sulfur and wax-that are either perishable or reusable (fig. 14).

Paper was another material used for intermediary processes; moistened with soapy water, it could be used to make a counterproof of an engraving. ${ }^{123}$ Even more versatile was carton, by which the author-practitioner designates paper pulp that can be molded into something akin to pasteboard or used to form reliefs of variable thickness (as is done with cartapesta); the vulnerability of carton to water needs to be managed but also can be exploited so that the plastic qualities of the pulp can be pressed toward more improvisatory ends. For instance, the author-practitioner uses carton to take impression of designs carved in stone and to adjust the alignment of objects within molds during the mold-making process, suggesting that to "make sure that the surface of your cast object directly lines up with the mold,... put a piece of carton of whatever thickness you wish." ${ }^{124}$ In the 1540 Pirotechnia, metalworker and mine manager Vannoccio Biringuccio (ca. 1480-1539) gave a purportedly firsthand description of the Italian artist Giambattista Pelori's method for making reproductive molds for sculptures, yet another use of paper for intermediary purposes, the process commencing by coating the sculpture to be reproduced in paper pulp, "just as masks are made." This initial layer is coated with several layers of a paste composed of flour and hide scrapings, then the whole is covered with linen scraps. After drying, this layer is cut off the statue, forming a mold, and made impermeable with Grecian pitch and wax, then poured with plaster to make multiple reproductions. Biringuccio notes that "these moulds were made with little expense; they were strong and unbreakable, light and easily carried to suitable places." 125

Such intermediary processes, which produced ephemeral objects and tools, could distinguish the craftsperson as a thorough and careful artist. Vasari described how sculptors made "Sketch-Models" about a foot high in wax or clay, to work out "the attitude and proportion" of the figure before they worked it in stone. These methods of working marked out the good and patient artist: "many errors in statues spring from this impatience of the artist to see the round

${ }^{122}$ Vasari, 1907, 165

${ }^{123}$ BnF MS Fr. 640, fol. $51^{\mathrm{r}}$.

${ }^{124}$ Tenzin Yewong Dongchung, "Understanding 'Carton," in Making and Knowing et al.

${ }^{125}$ Biringuccio, 331-32. 


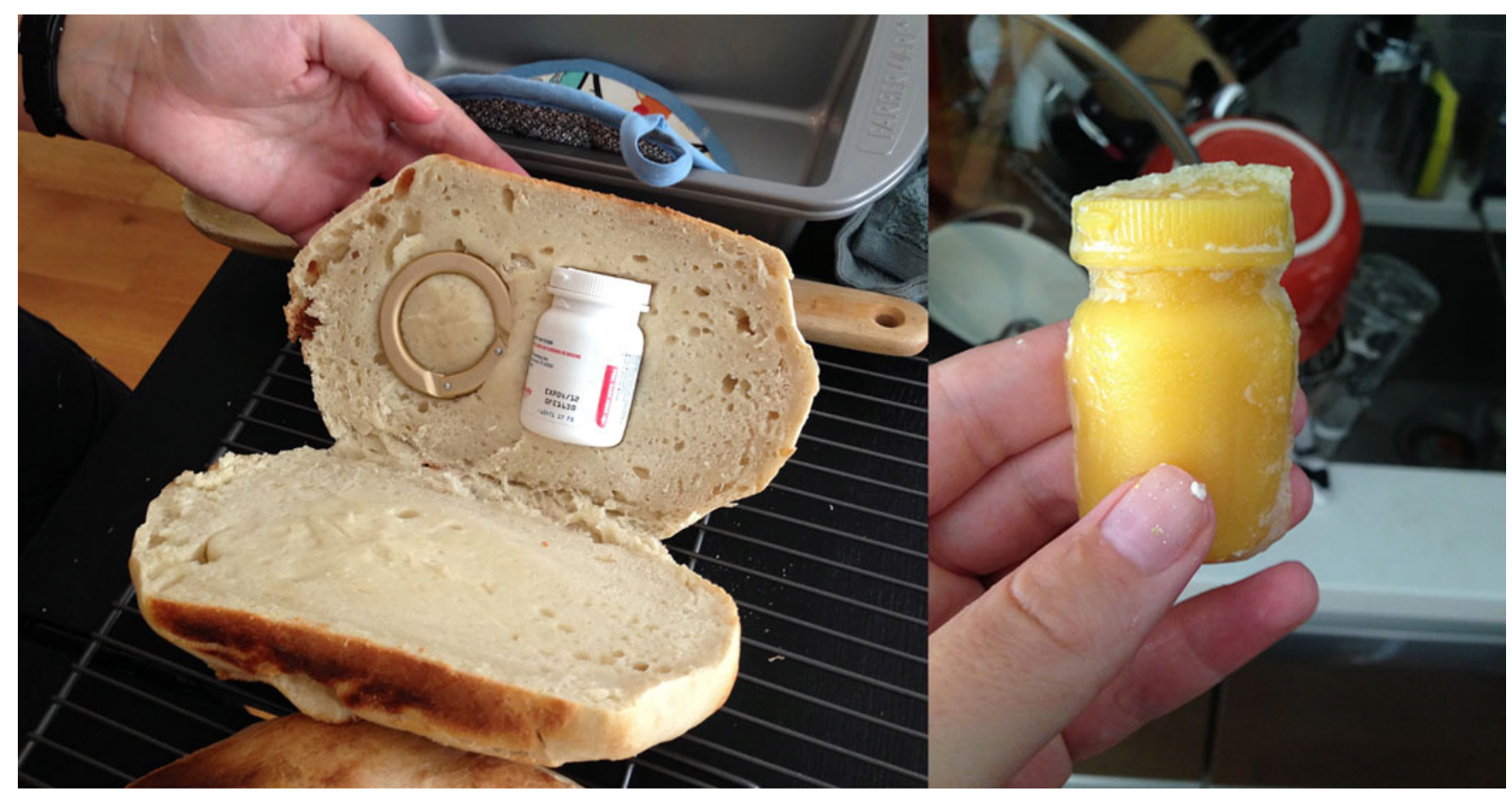

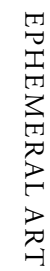

Figure 14. Breadmolding, following instructions in BnF MS Fr. 640, fol. 140v . The Making and Knowing Lab, 2014. (C) Making and Knowing Project. 
figure out of the block at once, so that often an error is revealed that can only be remedied by joining on pieces, as we have seen to be the habit of many modern artists." 126 The ephemeral production of sketch models or of sulfur and wax models cast in a breadmold demonstrates how the category of ephemeral art might be expanded beyond the bounds of festivals and performances. The fact that such intermediary models were employed to convince patrons of the feasibility or attractiveness of designs, thus forming a significant site of conversation and negotiation about aesthetics and the aims of art, also points to the larger importance of such ephemera for the history of art more generally.

\section{The Performance of Transformation and Transience}

Although we tend to associate ephemeral art with the temporary props, costumes, and scenery designed to serve performances like pageants, festivals, jousts, and theater, which were not necessarily meant to last, BnF MS Fr. 640 also casts a new light on the importance of the fleeting or ephemeral as a form of performance in itself. Some of the recipes in the manuscript describe sleight-of-hand tricks and other performances that involve the transformation-or feigned transformation - of one material into another for the sake of entertainment. ${ }^{127}$ Such transformations, which rely on an artist's knowledge of workshop materials and their properties, partake in a kind of ephemerality closely allied with artistic performance. For instance, instructions for the transmutation of red into white wine requires the artist to prepare a water dyed with brazilwood in imitation of red wine and then to "put a drop of lemon or orange juice in it $\&$ it will immediately turn white." To make the performance all the more convincing, the author-practitioner notes, "it can be drunk without danger." 128 Other such performances involve writing without ink (i.e., writing on paper with oil of sulfur and then turning it black under the heat of a lamp), ${ }^{129}$ making grains seem to pass from one vessel to another, ${ }^{130}$ boiling an egg in cold water without fire (using quicklime and sulfur), ${ }^{131}$ and melting a jewel placed in a box. ${ }^{132}$

The changeable nature of materials, and their transformation over time, was the very point of these performances. The tendency of materials to respond to one another and to the environment, and of living things to age, decay, and

${ }^{126}$ Vasari, 1907, “attitude and proportion," 148, and "errors," 152.

${ }^{127}$ Ann-Sophie Barwich, "Sleight of Hand," in Making and Knowing et al.

${ }^{128}$ BnF MS Fr. 640, fol. $43^{\mathrm{v}}$.

${ }^{129}$ BnF MS Fr. 640, fol. 46 . Olivia Clemens, "Sulfuric Acid for the Scribe," in Making and Knowing et al.

${ }^{130}$ BnF MS Fr. 640, fol. $35^{\mathrm{v}}$.

${ }^{131}$ BnF MS Fr. 640, fol. $35^{\mathrm{r}}$.

${ }^{132}$ BnF MS Fr. 640, fol. $34^{\mathrm{v}}$. 
alter, was of central importance to early modern artists who embraced and investigated transformation in their work. The transience of life was taken up by many craftsmen, such as the still-life painters who depicted the impermanence of living things in vanitas paintings, playing on the idea that art might depict nature but that nature would ultimately destroy art. The deep interest in grottos as contemplative spaces depended on their status as sites of generation, metamorphosis, and decay. ${ }^{133}$ Ruins similarly displayed the transformation of matter over time, and images in published works on architecture often show chipped stone, plants growing in the cracks, and other signs of decay to lend to the depicted designs the clout of antiquity (fig. 15). It is no coincidence that the ruins of ancient triumphal arches were made a feature of entries into Rome, such as that of Charles V in $1536 .{ }^{134}$ Temporary structures in early modern entries were sometimes even made to look like ruins, as in the 1596 entry of Henri IV to Rouen. The first arch he encountered on his entry was purposefully only partly finished, a depiction of ruined walls complete with life-size workers (sculpted in plaster) who were laying bricks and carrying buckets. ${ }^{135}$ Other entertainments during this entry also played with the idea of ruins, and, at the Rouen town hall, a garden of peace was constructed with a "terrace made of lead, surrounded with several flowerets and festoons, also of lead, halfbroken and painted so as to reveal their antiquity and their past ruin."136

\section{Imitation: Preserving Ephemeral Life}

While this profound interest in the transience of life, and the enactment and performance of material transformation were concerns for early modern craftspeople, the author-practitioner who compiled the entries in BnF MS Fr. 640 seems to have had a particular preoccupation with the preservation of the ephemera of nature. Indeed, if the author-practitioner was to have thought about the term ephemera at all, it would likely have been in the context of the fleeting nature of living things, such as insects or plants that were known to have particularly short life-spans; referencing this idea, Francis Bacon explained, "there are certain Flies that are called Ephemera that live but a day." 137 In his 1611 French-English dictionary, Randle Cotgrave defined the terms ephemere and ephemerique as something "that lasts but a day" such as a fever or an ague, or "May-Lillies."138

${ }^{133}$ See, for example, the engravings of Lorenz Stoer in Wood.

${ }^{134}$ Nuti, 128.

${ }^{135}$ McGowan, 56-58.

${ }^{136}$ See Discours de la joyeuse et triomphante entreé de tres-haut, tres-puissant et tres-magnanime prince Henri IIII (1599), as cited in McGowan, 59.

${ }^{137}$ Bacon, 176.

${ }^{138}$ Cotgrave. 




Figure 15. Sebastiano Serlio. Rusticated portal, in Regole generali di architetura (Venice: Francesco Marcolini, 1537), fol. $12^{\mathrm{r}}$. Avery Architectural and Fine Arts Library, Columbia University.

In BnF MS Fr. 640, entries abound for lifecasting processes, which capture and preserve in intricate detail the veining of leaves and the curl of petals, the body of the stag beetle, the scales of a lizard, and even the delicate wings of a fly by transforming organic materials into durable metal. ${ }^{139}$ The authorpractitioner's instructions demonstrate the lengths to which the lifecaster had to go in order to catch, preserve, kill, pose, mold, cast, and finally decorate the cast animals in order to make them lifelike. While snakes and lizards should be kept alive until just before they are posed and cast because they "wither" once

${ }^{139}$ BnF MS Fr. 640 , fols. $116^{\mathrm{r}}, 130^{\mathrm{v}}, 107^{\mathrm{r}}, 111^{\mathrm{v}}, 124^{\mathrm{v}}, 133^{\mathrm{r}}, 165^{\mathrm{v}}$. 
dead, ${ }^{140}$ he instructs that rats should be kept dead for a few days "to have them more handleable. For they stay rigid after their death, \& cannot be well fitted to their true shape until they are a little softened." 141 Other challenges, such as how to mold whiskers, feathers, and hairs "according to nature" are addressed. ${ }^{142}$ For example, he mentions that rats' "whiskers would be awkward to come out in the cast; you can therefore shave them with fire, like the tyrant of Syracuse \& afterward you can replace with natural silvered ones."143 Once the metal has been poured and hardened, they must then be painted "according to nature" to make the cast plant, insect, or animal look lifelike. ${ }^{144}$ A lifecast rose, he explains, "does not appear beautiful if it is not painted" (fig. 16). ${ }^{145}$

The author-practitioner also experimented with ways to preserve flowers and animals through drying. He gives instructions to preserve flowers "which last all year" through dehydration in sand or pickling in vinegar (fig. 17). ${ }^{146}$ Using the same technique "as for flowers," he suggests that animals can be dried in sand before being placed into an oven to completely dry out. ${ }^{147}$ Once dry, the animals (he mentions cats, rats, snakes, and birds) can be stitched together into chimera-like animal hybrids, of the kind often collected in Kunstkammern. ${ }^{148}$ But while the creatures thus created might be fantastical, he stresses the need for naturalism: "one places in the hollow of the eyes balls of lead or of wax, painted according to nature. One paints them with well-gummed ink so that they seem to be jet. One gives it a painted tongue, horns, wings \& similar fancies. Thus for rats $\&$ all animals" (fig. 18). ${ }^{149}$

Enlivenment through painting is also evident in the author-practitioner's interest in flesh tones. He gives instructions to use the pigment Florence lake, which "makes a beautiful vivid flesh color," 150 and in an entry entitled "Mirror," recommends: "When you make flesh colors, it is good to have a cristallin mirror, which represents nature well, and in which you will see if your shadows are soft enough or too crude. But do not look at it with a candle, for

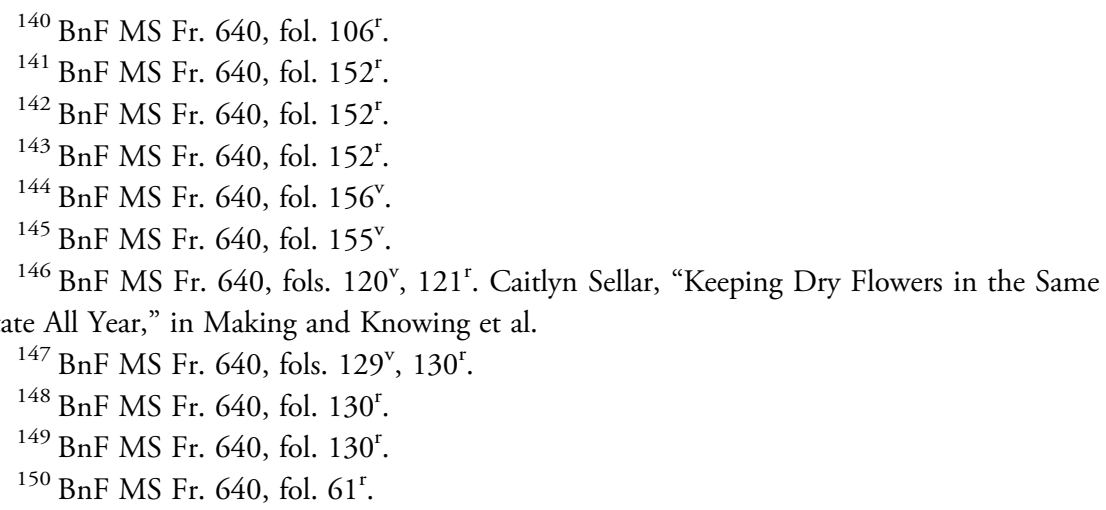






Figure 16. Lifecast rose, made following instructions in BnF MS Fr. 640, fol. 155 . Giulia Chiostrini and Jeffrey Palframan, The Making and Knowing Lab, 2015. (C) Making and Knowing Project.

firelight will make the shadows reddish. The painter also teaches himself with the mirror, for he sees in it what nature can do." ${ }^{151}$ This interest in observing and reproducing "what nature can do" connects to a widespread interest by

${ }^{151}$ BnF MS Fr. 640, fol. $65^{\mathrm{r}}$. 




Figure 17. Delphiniums two years after being preserved in sand, made following instructions in BnF MS Fr. 640, fols. $120^{\mathrm{v}}-121^{\mathrm{r}}$; Garder fleurs seiches en mesme estat toute lannee (For keeping dry flowers in the same state all year), Caitlyn Sellar, The Making and Knowing Lab, 2016. (C) Making and Knowing Project.

craftspeople in the early modern era to investigate and imitate nature, and in doing so, to improve upon transient life by making it more permanent through art.

While we might think of this desire to preserve life and imitate lifelikeness as mere illusionism, of a piece with the life-size sculpted busts gesturing from false 


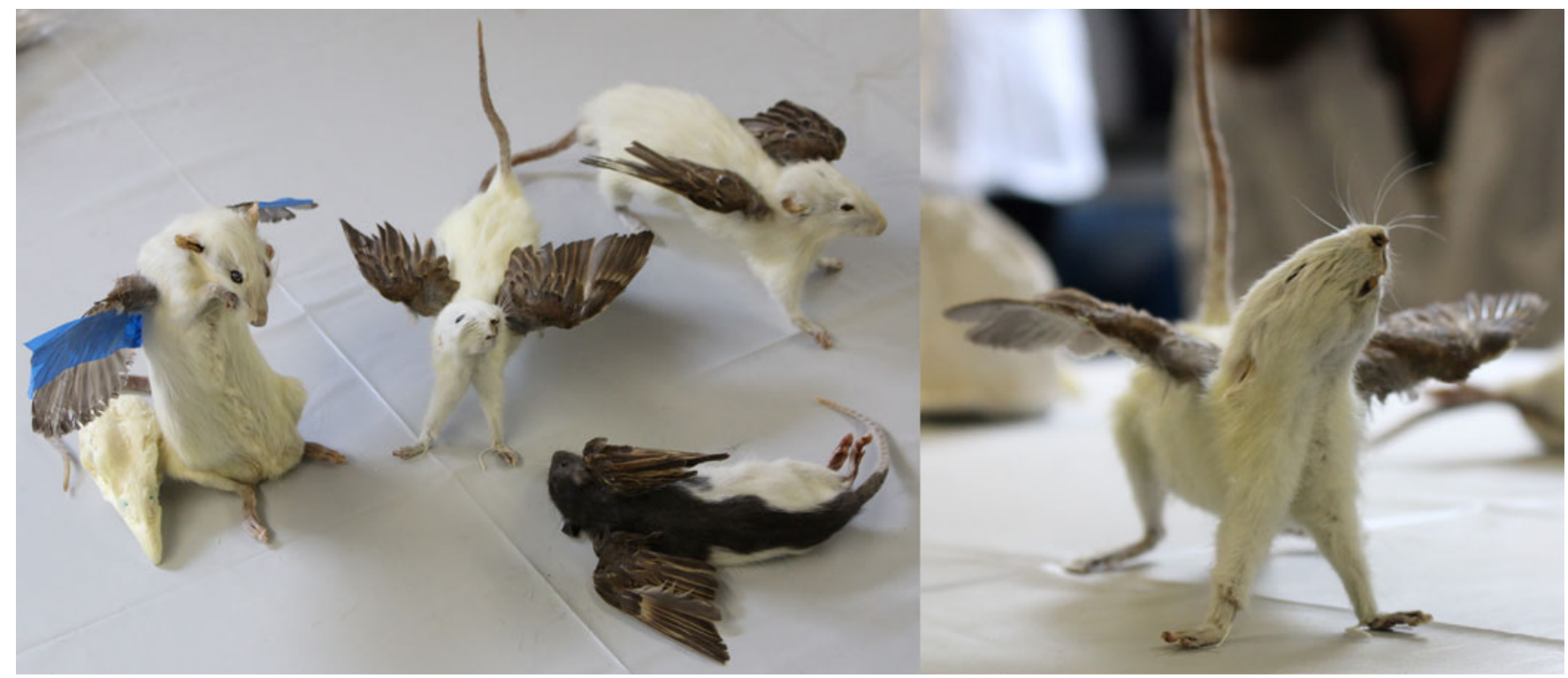

Figure 18. Animaulx seches au four (Animals dried in the oven), made following instructions in BnF MS Fr. 640, fol. 130 ${ }^{\mathrm{r}}$. Divya Anantharaman and the Making and Knowing Project, The Making and Knowing Lab, 2017. (C) Making and Knowing Project. 
windows that were popular in France in the fifteenth and sixteenth centuries, ${ }^{152}$ and with the clever material mimesis that underpinned the spectacular cardboard and plaster architecture of festivals, we can also see it as a deeper investigation on the part of artists and artisans more generally of what nature can do when transformed by the human hand.

\section{CONCLUSION}

The categories of art making explored in relation to the ephemeral in these last three sections-intermediary process, exploiting the transformational potential of materials in theatrical or performative ways, and the imitation and preservation of lifelikeness-all share not just in the characteristic processes of making art, but also in its larger aims. The production of ephemeral objects, such as the imitation of bronze sculpture in stucco or leather, that of stone sculpture in crystallized sugar, or rocky crags in parchment, indeed, all the counterfeiting (in the early modern sense of depicting or portraying) that went into a spectacle, was meant to impress not just by its monumentality, but also by its very artifice. Objects that looked solid and durable turned out to be confections of lightweight, easily manipulated materials that could be transported long distances, broken open or exploded in stunning displays meant to provoke wonder and memory, or treasured in modest homes. Making these objects, as well as those destined for individual or elite private viewing, almost always involved a mimetic representation, whether of an entire mise-en-scène or of individual materials such as jasper and coral. This attempt to appear "more natural than artificial," as one Toulouse commission specified, ${ }^{153}$ is a well-known feature of sixteenth-century art and culture, seen in myriad creative productions, from literary to material. But, more fundamentally from the perspective of this essay, all art-making processes involved the transformation of materials so that they took on properties foreign to their native state, whether by burning hard material to ash to make a molding matrix, liquefying solid substances in order to mold them (e.g., metal, and even stone and horn), transforming the carving properties of wax by adding tallow or sulfur, or pigmenting bright yellow sulfur to imitate various copper alloys for casting. In all making, artists had to conduct many trials, exploring by testing the properties and behavior of their materials, forming taxonomies and hypotheses about what materials will perform successfully, or simply about what materials in their environs could be useful. In such trials, they challenged their materials, pushing them to take on-to imitatethe often contrary properties of another material, in order to transform the

\footnotetext{
${ }^{152}$ Muñoz, 1:301-02.

${ }^{153}$ Archives départementales de la Haute-Garonne, 3E5208, fol. $322^{\mathrm{v}}$.
} 
coarse into the impalpably fine, the dry and "lean" into the "fatty" and workable, the hard or brittle into the malleable, the "sour" crack-prone tin into the "sweet" sonorous copper alloy used for bells, and the elements of earth and stones into the simulacra of all manner of precious things. ${ }^{154}$ Indeed, this transformation of materials in the service of imitation, whether for performative or for quotidian purposes, is simply a fundamental and everyday aspect of making art by working with and against (as well as by thinking with and against) natural materials. Considering this foundational dimension of art making with regard to ephemeral art allows us to see that this category cannot usefully be differentiated from other types of art either in its intended effects, its materials and techniques, or in the value assigned to it in the early modern world.

${ }^{154}$ The quoted words appear throughout BnF MS Fr. 640. See, for example, fols. $53^{\mathrm{r}}, 121^{\mathrm{v}}$, and $123^{\mathrm{r}-\mathrm{v}}$. 


\section{BIBLIOGRAPHY}

\section{Archival and Manuscript Sources}

Archives départementales de la Haute-Garonne, Toulouse, 1B1906, registre du parlement de Toulouse, copies d'actes divers enregistrés, 1560-65.

Archives départementales de la Haute-Garonne, Toulouse, 3E5208, registre du notaire Hilaire Lobeyrie, 1545.

Archives municipales de Toulouse (AMT), BB274, Annales manuscrites de la ville de Toulouse, $2^{\mathrm{e}}$ livre des Histoires, 1532-68.

AMT, CC1986, Comptabilité, comptes du trésorier, 1589.

AMT, CC2451, Comptabilité, pièces à l'appui des comptes et mandements relatifs à l'entrée du roi Charles IX à Toulouse, 1564-65.

AMT, CC2621, Comptabilité, pièces à l'appui des comptes et mandements de paiements, 1621.

Archives paroissiales de Saint-Sernin (APSS), Toulouse, B5, fols. 194-99, contrat de peinture pour le chœur, 1 May 1536.

Bibliothèque nationale de France, Paris (BnF), MS Fr. 640, Recueil de recettes et secrets concernant l'art du mouleur, de l'artificier et du peintre, n.d.

British Library, London, Cotton MS Augustus 111, fol. 18. Tent designs for the Field of Cloth of Gold, ca. 1520.

National Archives, Kew, Exchequer, Office of First Fruits and Tenths, and the Court of Augmentations, E36/229. Accounts of Richard Gibson for revels (connected with the Field of the Cloth of Gold), 22 April 1520-21 April 1521.

\section{Printed Sources}

Alard, Jean. Entrée du Roy à Tolose. Toulouse: R. Colomiés, 1622.

Albicante, Giovanni Alberto. Trattato del' intrar in Milano di Carlo V. Milan: Andreas Calvus, 1541.

Avery, Victoria, Melissa Calaresu, and Mary Laven, eds. Treasured Possessions from the Renaissance to the Enlightenment. London: Philip Wilson Publishers, 2015.

Bacon, Francis. Sylva Sylvarum or A Naturall History in ten centuries. London: William Rawley, 1627.

Becker, Jochen. "'Greater than Zeuxis and Apelles': Artists as Arguments in the Antwerp Entry of 1549." In Court Festivals of the European Renaissance: Art, Politics, and Performance, ed. J. R. Mulryne and Elizabeth Goldring, 171-98. Farnham: Ashgate, 2002.

Bergeron, David M. English Civic Pageantry, 1558-1642. Tempe, AZ: Arizona Center for Medieval and Renaissance Studies, 2003.

Biringuccio, Vannoccio. Pirotechnia, 1540. Ed. and trans. Cyril Stanley Smith and Martha Teach Gnudi. New York: Dover, 1990.

Bordes, François. "Formes et enjeux d'une mémoire urbaine au bas Moyen Age: Le premier 'Livre des Histoires' de Toulouse, 1295-1532." 5 vols. PhD diss., Université de Toulouse II-Le Mirail, 2006.

Brewer, J. S. ed. Letters and Papers, Foreign and Domestic, of the Reign of Henry VIII, vol. 4, part 2. London: Longman \& Co., 1872. 
Broecke, Lara. Cennino Cennini's "Il Libro dell'Arte." London: Archetype Publications, 2015. Bryant, Lawrence M. Ritual, Ceremony and the Changing Monarchy in France, 1350-1789. Farnham: Ashgate, 2010.

Bussels, Stijn. "All about Eve: Genesis and Gender in a Fireworks Display in the Antwerp Entry of Charles V and His Son Philip." In Drama, Performance and Debate: Theatre and Public Opinion in the Early Modern Period, ed. Jan Bloemendal, Elsa Strietman, and Peter Eversmann, 143-62. Leiden: Brill, 2013.

Cannon, Joanna, Jo Kirby, and Susie Nash, eds. Trade in Artists' Materials: Markets and Commerce in Europe to 1700. London: Archetype Publications, 2010.

Cartwright, John. "Forms and Their Uses: The Antwerp 'Ommegangen,' 1550-1700.” In Festive Drama: Papers from the Sixth Triennial Colloquium of the International Society for the Study of Medieval Theatre, Lancaster, 13-19 July, 1989, ed. Meg Twycross, 119-31. Cambridge: D. S. Brewer, 1996.

Catel, Guillaume. Mémoires de l'histoire du Languedoc. Toulouse: Pierre Bosc, 1633.

Cennini, Cennino d'Andrea. The Craftsman's Handbook: Il libro dell'Arte. Trans. Daniel V. Thompson. New York: Dover, 1960.

Cholcman, Tamar. Art on Paper: Ephemeral Art in the Low Countries: The Triumphal Entry of the Archdukes Albert and Isabella into Antwerp, 1599. Turnhout: Brepols, 2014.

Cholcman, Tamar. "Three Parts Divided: The Construction, Reconstruction, and Deconstruction of Festival Emblems." Emblematica: Essays in Word and Image 2 (2018): 153-83.

Cotgrave, Randle. A Dictionarie of the French and English Tongues. London: Adam Islip, 1611: http://www.pbm.com/ lindahl/cotgrave/.

Debord, Guy. The Society of the Spectacle. New York: Zone Books, 1995.

Debuiche, Colin. "Triomphes royaux dans les Entrées toulousaines des XVI et XVII e siècles." Les Cahiers de Framespa 11 (2012): http://journals.openedition.org/framespa/1872.

Debuiche, Colin. "Architecture et culture savante à Toulouse à la Renaissance." 5 vols. PhD diss., Université Toulouse II-Jean Jaurès, 2016.

de Estrella, Juan Cristóbal Calvete. El felicissimo viaie d'el mvy alto y mvy poderoso Principe Don Phelippe. Antwerp: Martin Nucio, 1552.

de Vries, Jan. The Industrious Revolution: Consumer Behaviour and the Household Economy, 1650 to the Present. Cambridge: Cambridge University Press, 2008.

Drogin, David J. "Art Patronage and Civic Identities in Renaissance Bologna." In The Court Cities of Northern Italy, ed. Charles M. Rosenberg, 244-324. Cambridge: Cambridge University Press, 2010.

Ferté, Patrick. "Toulouse et son université, relais de la Renaissance entre Espagne et Italie, 1430-1550.” In Échanges entre les universités européennes à la Renaissance, ed. Michel Bideaux and Marie-Madeleine Fragonard, 217-30. Geneva: Droz, 2003.

Foister, Susan. "Holbein's Paintings on Canvas: The Greenwich Festivities of 1527." In Hans Holbein: Paintings, Prints and Reception, ed. M. Roskill and J. O. Hand, 109-23. Washington, DC: National Gallery of Art, 2001.

Fonkenell, Guillaume. Le palais des Tuileries. Ed. Honoré Clair. Paris: Cité de l'architecture et du patrimoine, 2010. 
Gaggetta, Claudia. "Louis II d'Amboise et les fresques de la cathédrale Sainte-Cécile d'Albi.” In Le duché de Milan et les commanditaires français, 1499-1521, ed. Frédéric Elsig and Natale Mauro, 287-321. Rome: Viella, 2013.

Geertz, Clifford. Negara: The Theatre State in Nineteenth-Century Bali. Princeton, NJ: Princeton University Press, 1980.

Gevartius, Gaspar. Pompa introitus... Ferdinandi Austriaci. Antwerp: Johannes Meursius, 1642.

Giesey, Ralph E. Cérémonial et puissance souveraine: France, $X V^{e}-X V I I^{e}$ siècles. Paris: A. Colin, 1987.

Giroire, Cécile. "Être citoyen dans l'Empire." In De l'esclave à l'empereur: L'art romain dans les collections du Musée du Louvre, ed. Cécile Giroire and Daniel Roger, 116-63. Paris: Somogy, Musée du Louvre, 2008.

Goldthwaite, Richard A. Wealth and the Demand for Art in Italy, 1300-1600. Baltimore, MD: Johns Hopkins University Press, 1993.

Göttler, Christine. "Druon Antigoon, der unzerstörbare Koloss: Städtischer Raum, antiquarische Kultur und Künstlerwissen im Antwerpen des 16. Jahrhunderts.” In Skulptur und Platz: Raumbesetzung-Raumüberwindung-Interaktion, ed. Alessandro Nova and Stephanie Hanke, 141-72. Berlin: Deutscher Kunstverlag, 2014.

Grapheus, Cornelius. De seer wonderlijcke, schoone, triumphelijcke incompst. Antwerp: Pieter Coecke van Aelst, 1550a.

Grapheus, Cornelius. Spectaculorum in Susceptione Philippi Hisp. Prin. Antwerp: Pieter Coecke van Aelst, 1550b.

Guicciardini, Lodovico. Descrittione di tutti i paesi bassi, altrimenti detti germania inferiore. Antwerp: G. Silvius, 1567.

Heydenreich, Gunnar. Lucas Cranach the Elder: Painting Materials, Techniques and Workshop Practice. Amsterdam: Amsterdam University Press, 2007.

Julien, Pascal. "D'ors et de prières: Art et dévotion à Saint-Sernin de Toulouse, XVI ${ }^{\mathrm{e}}-\mathrm{XVIII}{ }^{\mathrm{e}}$ siècles." 3 vols. PhD diss., Université de Toulouse II-Le Mirail, 1996.

Krischel, Roland, ed. Tintoret, Naissance d'un génie. Paris: Les éditions Rmn-Grand Palais, 2018.

Kumar, Brinda. "Proxy Figures." In Like Life: Sculpture, Color, and the Body, ed. Luke Syson, 162-87. New Haven, CT: Yale University Press, 2018.

Kummer, Stefan. Anfänge und Ausbreitung der Stuckdekoration in Römischen Kirchenraum 1500-1600. Tübingen: E. Wasmuth, 1987.

Labrousse, Michel. Toulouse antique, des origines à rétablissement des Wisigoths. Paris: E. de Boccard, 1968.

Lafaille, Germain. Annales de la ville de Toulouse depuis la réunion de la comté de Toulouse à la couronne... Seconde partie. Toulouse: Colomyès, 1701.

Lasansky, D. Medina. The Renaissance Perfected: Architecture, Spectacle, and Tourism in Fascist Italy. University Park: Pennsylvania State University Press, 2004.

Lemerle, Frédérique. La Renaissance et les antiquités de la Gaule: L'architecture gallo-romaine vue par les architectes, antiquaires et voyageurs, des guerres d'Italie à la Fronde. Turnhout: Brepols, 2005. 
Leydi, Silvio. Sub umbra imperialis aquilae: Immagini del potere e consenso politico nella Milano di Carlo V. Florence: Olschki, 1999.

Making and Knowing Project, Pamela H. Smith, Naomi Rosenkranz, Tianna Helena Uchacz, Tillmann Taape, Clément Godbarge, Sophie Pitman, Jenny Boulboullé, Joel Klein, Donna Bilak, Marc Smith, and Terry Catapano, eds. Secrets of Craft and Nature in Renaissance France: A Digital Critical Edition and English Translation of BnF Ms. Fr. 640, http://edition640.makingandknowing.org. New York: The Making and Knowing Project, 2020.

Maravall, José Antonio. Culture of the Baroque: Analysis of a Historical Structure. Trans. Terry Cochran. Minneapolis: University of Minnesota Press, 1986.

Marin, Louis. Portrait of the King. Trans. Martha M. Houle. Minneapolis: University of Minnesota Press, 1988.

McGowan, Margaret. "Henry IV as Architect and Restorer of the State: His Entry into Rouen, 16 October 1596." In Ceremonial Entries in Early Modern Europe, ed. J. R. Mulryne, with Maria Ines Aliverti and Anna-Maria Testaverde, 53-76. Farnham, Ashgate, 2015.

McGrath, Elizabeth. "Rubens's Arch of the Mint." Journal of the Warburg and Courtauld Institutes 37 (1974): 191-217.

Meadow, Mark A. "Ritual and Civic Identity in Philip II's 1549 Antwerp Blijde Incompst." In Hof, Staats-en Stadsceremonies, ed. Reindert Falkenburg, Mark A. Meadow, Johannes Leenderd de Jong, et al., 37-67. Zwolle: Waanders, 1999.

Mesuret, Robert. Évocation du Vieux Toulouse. Paris: Éditions de Minuit, 1960.

Montagu, Jennifer. Roman Baroque Sculpture: The Industry of Art. New Haven, CT: Yale University Press, 1992.

Muñoz, Sarah. "Célébrer et paraitre: Les têtes en médaillon sculptées dans l'architecture de la Renaissance en France.” 3 vols. PhD diss., Université Toulouse II-Jean Jaurès, 2016.

Nash, Susie. "'Pour couleurs et autres choses prise de lui. . .': The Supply, Acquisition, Cost and Employment of Painters' Materials at the Burgundian Court, c.1375-1419.” In Trade in Artists' Materials: Markets and Commerce in Europe to 1700, ed. Joanna Cannon, Jo Kirby, and Susie Nash, 97-182. London: Archetype Publications, 2010.

Neilson, Christina. Practice and Theory in the Italian Renaissance Workshop: Verrocchio and the Epistemology of Making Art. Cambridge: Cambridge University Press, 2019.

Neven, Sylvie. The Strasbourg Manuscript: A Medieval Tradition of Artists' Recipe Collections, 1400-1570. London: Archetype Publications, 2016.

Nuti, Lucia. "Re-Moulding the City: The Roman Possessi in the First Half of the Sixteenth Century." In Ceremonial Entries in Early Modern Europe: The Iconography of Power, ed. J. R. Mulryne, Maria Ines Aliverti, and Anna-Maria Testaverde, 113-34. Farnham: Ashgate, 2015.

O’Malley, Michelle, and Evelyn Welch, eds. The Material Renaissance. Manchester: Manchester University Press, 2007.

Pascal, Blaise. Pensées. Ed. Louis Lafuma. 2nd ed. Paris: Delmas, 1952.

Pepys, Samuel. The Diary of Samuel Pepys: A New and Complete Transcription, vol. 2. Ed.

Robert Latham and William Matthews. Berkeley: University of California Press, 2000.

Plat, Hugh. The jevvel house of art and nature. London: Bernard Alsop, 1653.

Pleij, Herman. De sneeuwpoppen van 1511: Literatuur en Stadscultuur tussen Middeleeuwen en Moderne Tijd. Amsterdam: Meulenhoff, 1988. 
Russell, Nicolas. "Construction et représentation de la mémoire collective dans les entrées triomphales au XVI ${ }^{\mathrm{e}}$ siècle." Renaissance \& Reformation/Renaissance et Reforme 32.1 (2009): $53-72$.

Sabatier, Gérard. Le Prince et les arts: Stratégies figuratives de la monarchie française, de la Renaissance aux Lumières. Seyssel: Champ Vallon, 2010.

Schneider, Robert A. Public Life in Toulouse 1463-1789: From Municipal Republic to Cosmopolitan City. Ithaca, NY: Cornell University Press, 1989.

Scholten, Frits. "Malleable Marble: The Antwerp Snow Sculptures of 1772." In Meaning in Materials, ed. Ann-Sophie Lehman, 266-95. Leiden: Brill, 2013.

Tierney, Elaine. "Contested Ideals: Designing and Making Temporary Structures for the Entrée of Louis XIV into Paris, August 1660.” In Architectures of Festival in Early Modern Europe: Fashioning and Re-Fashioning Urban and Courtly Space, ed. J. R. Mulryne, Krista de Jonge, Pieter Martens, et al., 139-67. London: Routledge, 2018.

Toulouse Renaissance. Ed. Pascal Julien. Paris: Somogy éditions d'art; Toulouse: Musée des Augustins, 2018. Exhibition catalogue.

Tuohy, Thomas. "The Ephemera of Magnificence: Sports; Feats of Arms; Theatre; Triumphal Entries; Banquets." In Herculean Ferrara: Ercole d'Este 1471-1505, and the Invention of a Ducal Capital, ed. Thomas Tuohy, 234-76. Cambridge: Cambridge University Press, 1996.

Van Bruaene, Anne-Laure. "Spectacle and Spin for a Spurned Prince: Civic Strategies in the Entry Ceremonies of the Duke of Anjou in Antwerp, Bruges and Ghent, 1582." Journal of Early Modern History 11.4 (2007): 263-84.

Vasari, Giorgio. Vasari on Technique. Trans. Louisa Maclehose. Ed. G. Baldwin Brown. London: J. M. Dent, 1907.

Vasari, Giorgio. Lives of the Most Eminent Painters, Sculptors \& Architects. Trans. Gaston du C. De Vere. 10 vols. London: Philip Lee Warner, 1912-15.

Visentin, Hélène, and Nicolas Russell. "The Multilayered Production of Meaning in SixteenthCentury French Ceremonial Entries." In French Ceremonial Entries in the Sixteenth Century, ed. Hélène Visentin and Nicolas Russell, 15-26. Toronto: Centre for Reformation and Renaissance Studies, 2007.

Weigert, Laura. French Visual Culture and the Making of Medieval Theater. Cambridge: Cambridge University Press, 2015.

Werrett, Simon. "Picturing Fireworks." The Public Domain Review. https://publicdomain review.org/essay/picturing-pyrotechnics.

Wiggins, Martin, and Catherine Richardson, eds. British Drama, 1533-1642: A Catalogue, vol. VI: 1609-16. Oxford: Oxford University Press, 2015.

Wilson, Jean C. "Workshop Patterns and the Production of Paintings in Sixteenth-Century Bruges." Burlington Magazine 132.1049 (1990): 523-27.

Wolfthal, Diane. "Agnes van Den Bossche: Early Netherlandish Painter." Woman's Art Journal 6.1 (1985): 8-11.

Wood, Christopher S. "The Perspective Treatise in Ruins: Lorenz Stoer, Geometria et Perspectiva, 1567." In The Treatise on Perspective: Published and Unpublished, ed. Lyle Massey, 235-57.

New Haven, CT: Yale University Press for the National Gallery of Art, 2003.

Zolli, Daniel. “Donatello's Promiscuous Technique.” PhD diss., Harvard University, 2016. 